\title{
Understanding the performance and mechanism of Mg-containing oxides as support catalysts in the thermal dry reforming of methane
}

\author{
Nor Fazila Khairudin, Mohd Farid Fahmi Sukri, Mehrnoush Khavarian \\ and Abdul Rahman Mohamed ${ }^{*} \S$
}

\author{
Review \\ Address: \\ School of Chemical Engineering, Universiti Sains Malaysia, 14300 \\ Nibong Tebal, Pulau Pinang, Malaysia \\ Email: \\ Abdul Rahman Mohamed* - chrahman@usm.my \\ * Corresponding author \\ § Tel.: +604 599 6410; Fax: +604 5996908 \\ Keywords: \\ carbon formation; catalyst development; dry reforming of methane; \\ magnesium catalyst; mechanism
}

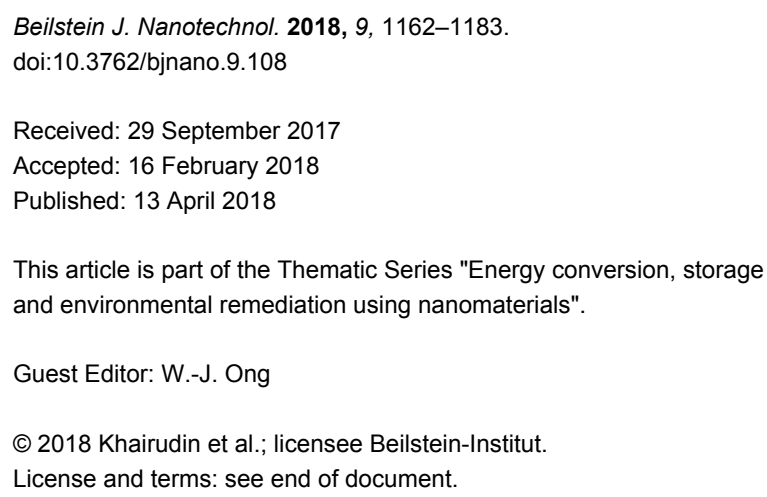

\begin{abstract}
Dry reforming of methane (DRM) is one of the more promising methods for syngas (synthetic gas) production and co-utilization of methane and carbon dioxide, which are the main greenhouse gases. Magnesium is commonly applied in a Ni-based catalyst in DRM to improve catalyst performance and inhibit carbon deposition. The aim of this review is to gain better insight into recent developments on the use of $\mathrm{Mg}$ as a support or promoter for DRM catalysts. Its high basicity and high thermal stability make Mg suitable for introduction into the highly endothermic reaction of DRM. The introduction of $\mathrm{Mg}$ as a support or promoter for Ni-based catalysts allows for good metal dispersion on the catalyst surface, which consequently facilitates high catalytic activity and low catalyst deactivation. The mechanism of DRM and carbon formation and reduction are reviewed. This work further explores how different constraints, such as the synthesis method, metal loading, pretreatment, and operating conditions, influence the dry reforming reactions and product yields. In this review, different strategies for enhancing catalytic activity and the effect of metal dispersion on Mg-containing oxide catalysts are highlighted.
\end{abstract}

\section{Review}

\section{Introduction}

Global warming is a present critical issue resulting from the excessive production of greenhouse gases, particularly carbon dioxide and methane $\left(\mathrm{CO}_{2}\right.$ and $\left.\mathrm{CH}_{4}\right)$. This phenomenon is attri- buted to human dependence on fossil fuels to meet the high energy demands of the rapidly increasing world population. Therefore, one of the solutions to mitigate the emission of 
greenhouse gases is to utilize these gases to yield new products, such as hydrogen or syngas (synthetic gas) [1-4]. Three principal technologies used for the production of syngas are steam reforming [5-7], partial oxidation [8-10], and dry reforming of methane (DRM) [11-13]. Among these technologies, DRM has attracted a growing body of research because of its potential to simultaneously utilize both carbon dioxide and methane gases. DRM is the most promising approach because the $\mathrm{H}_{2} / \mathrm{CO}$ ratio for this reaction favors the Fischer-Tropsch synthesis [14,15]. DRM is yet to be commercialized on an industrial scale, as this method still has several issues and limitations, including the following: (i) the endothermic nature of the DRM reaction, (ii) catalyst deactivation, and (iii) the $\mathrm{H}_{2} / \mathrm{CO}$ product ratio is lower than unity due to the occurrence of a reverse water-gas shift (RWGS) reaction, $\mathrm{CO}_{2}+\mathrm{H}_{2} \leftrightarrow \mathrm{CO}+\mathrm{H}_{2} \mathrm{O}$. However, the major obstacle in implementing this technology is catalyst deactivation, which is defined as the susceptibility to carbon deposition and sintering of both support and active metal particles [16-18]. The loss of catalytic activity or selectivity over time of production affects the cost of catalyst replacement, process shutdown, and product quality and quantity. Numerous researchers have reported that noble metal-based catalysts, such as $\mathrm{Pt}, \mathrm{Rh}, \mathrm{Pd}$, $\mathrm{Ru}$, and $\mathrm{Ir}$, exhibit high activity and resistance toward carbon formation [19-21]. However, these noble metals are associated with high cost and low availability, so non-noble metals, such as Ni [18,22-24], Fe [25-28], and Co [29,30] are most often used. Among the non-noble metals, Ni has been frequently chosen as an active catalyst metal owing to its vast availability, excellent activity, substantial redox characteristic, and relatively low cost [31]. However, Ni-based catalysts suffer from significant carbon deposition, which leads to carbon deactivation $[32,33]$. Recently, numerous attempts have been made to minimize carbon deposition on the catalyst surface in a DRM reaction. A high dispersion of active metal over the support is an effective approach to decrease carbon deposition by producing catalysts of small particle size [19,28,31,34-40]. In addition, a high dispersion of metal particles enhances the interaction between metal and support, consequently reducing carbon deposition [40-44].

One other alternative for inhibiting carbon deposition, as suggested by researchers, is the application of a second metal oxide, such as alkali or alkaline earth metal oxides, to the DRM catalyst to alter the catalyst acidity [39,45-48]. Numerous publications have reported on the ability of Mg-containing oxide catalysts to decrease the rate of carbon formation in a DRM reaction [18,19,49-54]. $\mathrm{MgO}$ exhibits superior surface and catalytic characteristics as a catalyst support combined with a high dispersion of small active particles for suppressing carbon formation [55]. The decreased carbon formation in DRM is due to the high basicity of $\mathrm{MgO}$ to capture $\mathrm{CO}_{2}$, thereby accelerating the overall reaction $[34,49,51]$. Furthermore, its characteristics such as high thermal stability, high melting point, and low cost make $\mathrm{MgO}$ a promising component in endothermic reactions, especially in the DRM process $[18,34,49]$.

Therefore, this review discusses the research regarding the DRM reaction over Mg-containing oxide catalysts as conducted by numerous researchers to assist in the reaction for decreasing carbon formation and to improve catalyst activity, selectivity, and stability. To date, an incorporated mechanism for carbon deposition and removal has yet to be proposed and is still being debated among researchers. The present review mainly focuses on the mechanism of DRM, carbon formation and removal, the role of Mg-containing oxide catalysts in resistance to catalyst deactivation, Mg-containing oxide catalyst development, and the effect of reaction conditions on catalyst performance.

\section{Thermodynamic analysis}

Thermodynamic analysis of a reaction is important for the theoretical study on the behavior of the process and the possible reaction conditions. A thermodynamic study could provide a basis for experimental investigation of the DRM reaction because the chemical reactions are conducted under equilibrium conditions $[13,56]$. Pressure, temperature and the composition of reactants $\left(\mathrm{CH}_{4}\right.$ and $\left.\mathrm{CO}_{2}\right)$ are emphasized the most in thermodynamic studies using Gibbs free energy minimization technique $[13,57,58]$.

\section{Effect of temperature and pressure in DRM}

In a DRM reaction, the conversion of $\mathrm{CH}_{4}$ and $\mathrm{CO}_{2}$ increases with an increase in temperature. This is because the DRM reaction is endothermic. In addition the reaction temperature in the DRM is the most important factor compared to pressure and reactant composition. As the temperature increases, the reaction approximately reaches complete conversion and equilibrium is achieved. Nikoo et al. [56] investigated the effect of temperature on the equilibrium conversion of $\mathrm{CH}_{4}$ and $\mathrm{CO}_{2}$ in a DRM reaction using Gibbs free energy minimization method. They showed that at low temperatures, $T_{\text {rxn }}<800{ }^{\circ} \mathrm{C}(1073 \mathrm{~K})$, the equilibrium conversion of $\mathrm{CH}_{4}$ was different for different ratios of $\mathrm{CO}_{2} / \mathrm{CH}_{4}$. However, when the temperature increased, $T_{\text {rxn }} \geq 800{ }^{\circ} \mathrm{C}$, for ratios of 2 and 3 , the equilibrium conversion of $\mathrm{CH}_{4}$ was $100 \%$ and for ratios 0.5 and 1 , the conversion reached $95 \%$ and later increased up to $100 \%$ at a temperature of $1200{ }^{\circ} \mathrm{C}$. They also found that the equilibrium conversion of $\mathrm{CO}_{2}$ decreased as the temperature was increased from $300{ }^{\circ} \mathrm{C}$ $(573 \mathrm{~K})$ to $600{ }^{\circ} \mathrm{C}(873 \mathrm{~K})$. This was due to the reaction of $\mathrm{CO}_{2}$ with two moles of $\mathrm{H}_{2}$ (Equation 1) to produce a large amount of carbon deposits and water since the reaction is exothermic and favorable at lower temperature. 
$\mathrm{CO}_{2}(\mathrm{~g})+2 \mathrm{H}_{2} \leftrightarrow \mathrm{C}+2 \mathrm{H}_{2} \mathrm{O} \quad \Delta H_{298 \mathrm{~K}}=-90 \mathrm{~kJ} / \mathrm{mol}(1)$

However, the equilibrium conversion of $\mathrm{CO}_{2}$ increased as the temperature was increased to above $600{ }^{\circ} \mathrm{C}(873 \mathrm{~K})$, as Equation 2 and Equation 3 are favorable at high temperature. The results obtained for the equilibrium conversion of $\mathrm{CH}_{4}$ and $\mathrm{CO}_{2}$ showed that the ratio of unity was the best ratio to obtain a balanced conversion between $\mathrm{CH}_{4}$ and $\mathrm{CO}_{2}$. As the ratio of $\mathrm{CO}_{2} / \mathrm{CH}_{4}$ increased, $\mathrm{CH}_{4}$ became the limiting reactant and $\mathrm{CO}_{2}$ was the excess reactant, so the limiting reactant was consumed more and the consumption of excess reactant was not completed.

$$
\begin{array}{cc}
\mathrm{CH}_{4}+\mathrm{CO}_{2} \leftrightarrow 2 \mathrm{CO}+2 \mathrm{H}_{2} & \Delta H_{298 \mathrm{~K}}=247 \mathrm{~kJ} / \mathrm{mol} \\
\mathrm{CO}_{2}+\mathrm{H}_{2} \leftrightarrow \mathrm{CO}+\mathrm{H}_{2} \mathrm{O} \quad \Delta H_{298 \mathrm{~K}}=41.4 \mathrm{~kJ} / \mathrm{mol}
\end{array}
$$

In terms of catalytic performance, pressure is one of the factors which influences the activity of the catalyst in a DRM reaction because as the pressure increases, carbon deposition increases significantly. In addition, according to Chein et al. [13], the carbon deposit could increase to approximately $50 \%$ from atmospheric to 10 bar. It has been reported that as the conversion of reactants $\left(\mathrm{CH}_{4}\right.$ and $\left.\mathrm{CO}_{2}\right)$ decreased, the yield of $\mathrm{H}_{2}$ and $\mathrm{CO}$ also decreased and the carbon deposition increased with an increase in pressure, which indicates that the DRM reaction is not favored at high pressure $[13,59,60]$. This is probability because the collision of gas molecule and the active site surface of the catalyst increases and the surface concentration along with residence time for the $\mathrm{CH}_{x}$ species also increase as the pressure increases. The increase in pressure leads to a synchronization of carbon deposition and consumption whereby the rate of carbon deposition is higher than the consumption rate, resulting in catalyst deactivation due to carbon deposition [61].

In the DRM reaction, the carbon deposition and side reactions, especially the RWGS reaction, are known as a major problem to the stability of the catalyst and prevent a high yield of syngas production $\left(\mathrm{H}_{2}\right.$ and $\left.\mathrm{CO}\right)$ [62]. Jafarbegloo et al. [63] also reported that the mole fraction of $\mathrm{H}_{2} \mathrm{O}$ increased as the pressure in the DRM reaction was increased. Even at atmospheric pressure, the formation of $\mathrm{H}_{2} \mathrm{O}$ was observed which indicates the occurrence of the RWGS reaction. This shows that the RWGS in the DRM reaction can be reduced but it cannot be eliminated according to thermodynamic equilibrium.

\section{Role of inert gas in DRM}

The use of inert gases such as $\mathrm{N}_{2}$ can affect the DRM reaction especially in methane cracking (Equation 4). Figure 1 shows the relationship between $\mathrm{CH}_{4}, \mathrm{H}_{2}$, inert gas, and temperature in a ternary composition diagram [64]. The dotted line represents the presence of inert gas in the equilibrium mixture of $\mathrm{CH}_{4}$ and $\mathrm{H}_{2}$ at $500{ }^{\circ} \mathrm{C}$. As the mole fraction of the inert gas increases, the reaction will increasingly favor thermodynamic $\mathrm{CH}_{4}$ decomposition. Furthermore, it can be said that at higher temperature, the inert gas does not affect the DRM reaction in terms of carbon deposition, so the effect of inert gas at high temperature could be negligible.

$$
\mathrm{CH}_{4} \leftrightarrow \mathrm{C}+2 \mathrm{H}_{2} \quad \Delta H_{298 \mathrm{~K}}=74.9 \mathrm{~kJ} / \mathrm{mol}
$$

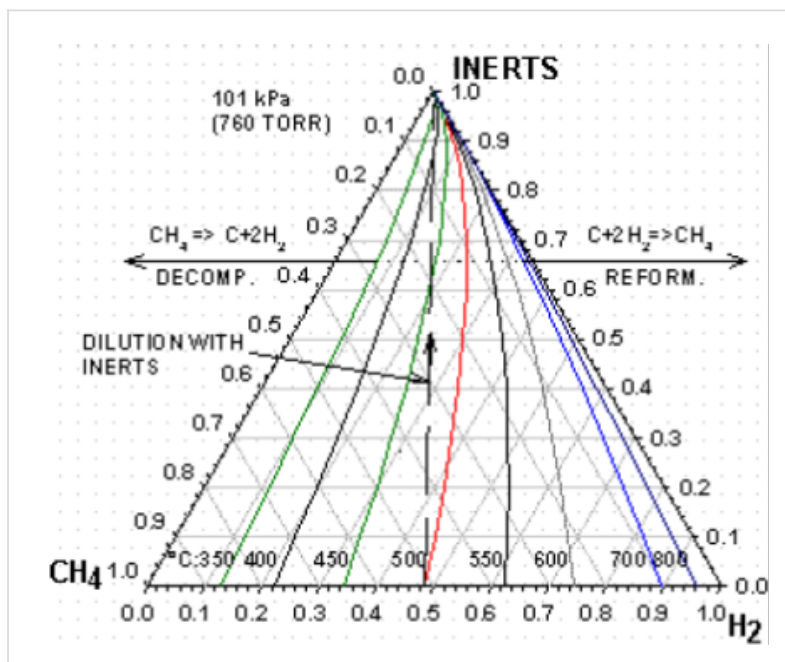

Figure 1: Methane decomposition equilibrium in the presence of inert gas at different temperatures. Reprinted with permission from [64], copyright 2002 Taylor and Francis Group.

\section{DRM reaction mechanism}

DRM is an endothermic reaction favored at high temperature and a low pressure. The reaction mechanism is extremely important for understanding the involved processes or for determining a solution to overcome catalyst deactivation. In general, the reaction mechanism depends on the choice of catalyst and all reactions involved in the DRM process. The overall proposed mechanism of the DRM reaction in the literature $[57,65,66]$ follows three main steps: i) adsorption of $\mathrm{CH}_{x}$ $(x=0-4)$ and $\mathrm{H}$, and decomposition of $\mathrm{CH}_{4}$, ii) adsorption and activation of $\mathrm{CO}_{2}$ and iii) oxidation of $\mathrm{CH}$ and $\mathrm{C}$.

The role of the various catalyst constituents is important for the adsorption of reactants onto the catalyst surface and for the weakening of the chemical bonds of the reactant for the dissociation process. In one proposal, $\mathrm{CH}_{4}$ activation was found to take place on the active sites. Niu et al. [66] proposed the mechanism of DRM over a Pt catalyst as shown in Equation 5. Equation 5 shows the adsorption of methane on the metal catalyst followed by dehydrogenation to produce hydrogen and a hydrocarbon species $\mathrm{CH}_{x}(x=0-3)$. When $x=0$, carbon deposition 
occurs on the metal surface. Equation 6 describes the dissociation of $\mathrm{CO}_{2}$ into $\mathrm{CO}$ and $\mathrm{O}$. The produced atomic $\mathrm{H}$ from the dehydrogenation process activates $\mathrm{CO}_{2}$ to form $\mathrm{COOH}$ before decomposition into $\mathrm{CO}$ and $\mathrm{OH}$, as displayed in Equation 7. The $\mathrm{H}$ adsorbed by the catalyst surface activates $\mathrm{CO}_{2}$ to form $\mathrm{HCOO}^{*}$, which then dissociates into $\mathrm{CHO}^{*}$ and $\mathrm{H}^{*}$ (Equation 8). Then, in the following step (Equation 9), $\mathrm{CH}^{*}$ is oxidized to produce $\mathrm{CHO}^{*} / \mathrm{COH}^{*}$ and subsequently decomposes to $\mathrm{CO}^{*}$ and $\mathrm{H}^{*}$. Equation 10 depicts the oxidation of $\mathrm{CH}^{*}$ by $\mathrm{OH}^{*}$, becoming $\mathrm{CHOH}^{*}$ as an intermediate before dissociating into $\mathrm{CHO}^{*} / \mathrm{COH}^{*}$ and $\mathrm{H}^{*}$. Finally, Equation 11 shows the oxidation of $\mathrm{C}^{*}$ by $\mathrm{O}^{*}$ and $\mathrm{OH}^{*}$, resulting in $\mathrm{CO}^{*}$ and $\mathrm{COH}^{*}$, respectively. The large majority of the adsorbed hydrogen species are then recombined to produce the hydrogen molecules that subsequently desorb into the gaseous phase. In the following equations, the symbol $(*)$ indicates the surface of the catalyst active site in the reactions.

$$
\begin{aligned}
& \mathrm{CH}_{x(x=1-4)^{*}}+* \rightarrow \mathrm{CH}_{x(x=0-3)^{*}}+\mathrm{H}^{*} \\
& \mathrm{CO}_{2}^{*}+* \rightarrow \mathrm{CO}^{*}+\mathrm{O}^{*} \\
& \mathrm{CO}_{2}{ }^{*}+\mathrm{H}^{*} \rightarrow \mathrm{COOH}^{*}+* \rightarrow \mathrm{CO}^{*}+\mathrm{OH}^{*} \\
& \mathrm{CO}_{2}{ }^{*}+\mathrm{H}^{*} \rightarrow \mathrm{HCOO}^{*}+* \rightarrow \mathrm{CHO}^{*}+\mathrm{O}^{*} \\
& \mathrm{CH}^{*}+\mathrm{O}^{*} \rightarrow \mathrm{CHO}^{*} / \mathrm{COH}^{*}+* \rightarrow \mathrm{CO}^{*}+\mathrm{H}^{*} \\
& \mathrm{CH}^{*}+\mathrm{OH}^{*} \rightarrow \mathrm{CHOH}^{*}+* \rightarrow \mathrm{CHO}^{*} / \mathrm{COH}^{*}+\mathrm{H}^{*}(10) \\
& \mathrm{C}^{*}+\mathrm{O}^{*} / \mathrm{OH}^{*} \rightarrow \mathrm{CO}^{*} / \mathrm{COH}^{*}
\end{aligned}
$$

Another reaction mechanism, in which the activation of $\mathrm{CO}_{2}$ takes place on the surface of the support rather than the metal active site, was proposed by Fan et al. [65] for catalysts with basic supports, such as $\mathrm{MgO}$. In this mechanism, $\mathrm{CO}_{2}$ is adsorbed on the catalyst support in the vicinity of the metal particles, $\mathrm{CO}_{2}$ ( $\left.\mathrm{g}\right) \leftrightarrow \mathrm{CO}_{2}$ (support), to form carbonate species, $\mathrm{CO}_{2}$ (support) $+\mathrm{O}^{2-} \leftrightarrow \mathrm{CO}_{3}{ }^{2-}$ (support). Then, the carbonate was reduced by the adsorbed hydrogen $\left(\mathrm{CO}_{3}{ }^{2-}\right.$ (support) $+2 \mathrm{H}$ $\leftrightarrow \mathrm{HCO}_{2}{ }^{-}$(support) $+\mathrm{OH}^{-}$) to form $\mathrm{CO}[65,67,68]$. When $\mathrm{Mg}$ or $\mathrm{MgO}$ are added as promoters, $\mathrm{CO}_{2}$ is supposedly adsorbed onto the promoter and dissociated into $\mathrm{CO}$ and $\mathrm{O}$ (Equation 4). Then, the surface reaction occurs between the adsorbed oxygen on the promoter followed by deposition of carbon from $\mathrm{CH}_{4}$ decomposition on the catalyst active sites to form $\mathrm{CO}\left(\mathrm{O}^{*}+\mathrm{C}^{*} \rightarrow\right.$ $\left.\mathrm{CO}^{*}\right)$.

\section{Mechanism of carbon formation/removal in DRM}

Catalyst deactivation is usually influenced by metal sintering and carbon deposition. Metal sintering may be caused by exothermic reactions and/or local overheating [69]. Carbon deposition is the major problem in the DRM; carbon deposition originates from reactions such as $\mathrm{CH}_{4}$ decomposition (Equation 4), the Boudouard reaction (Equation 12), and CO reduction reaction (Equation 13).

$$
\begin{gathered}
2 \mathrm{CO} \rightarrow \mathrm{C}+\mathrm{CO}_{2} \Delta H_{298 \mathrm{~K}}=-172.4 \mathrm{~kJ} / \mathrm{mol} \\
\mathrm{CO}+\mathrm{H}_{2} \rightarrow \mathrm{H}_{2} \mathrm{O}+\mathrm{C} \quad \Delta H_{298 \mathrm{~K}}=-131.0 \mathrm{~kJ} / \mathrm{mol}
\end{gathered}
$$

Several studies have attempted to discover the phenomena of carbon deposition in terms of its formation and variations in chemical structure with the applied catalysts, feed gas ratio, and other process conditions [24,68,70-76]. In the past decade, most researchers have focused on catalyst development to decrease or eliminate carbon formation and have struggled to understand the mechanism of carbon formation. Different mechanisms according to reactant activation and type of applied catalyst have been proposed for the growth of carbon on the catalyst surface. Lobo et al. [77] suggested the basic idea for the mechanism of carbon formation based on three main steps: i) carbon formation from the surface reaction occurring from the decomposition of hydrocarbons on the metal surface; (ii) dispersion of carbon atoms through the bulk of active metal; and (iii) the progression of the deposited carbon. Wang et al. [73] proposed conducting the DRM reaction over Ni metal through four main pathways, namely, $\mathrm{CH}_{4}$ dissociation, $\mathrm{CO}_{2}$ dissociation, $\mathrm{C}$ oxidation, and $\mathrm{CH}$ oxidation, as shown in Figure 2. Interestingly, carbon formed only through the $\mathrm{C}$ oxidation pathway; meanwhile, $\mathrm{CH}$ was transformed to $\mathrm{CO}$ through $\mathrm{CHO}$ in the $\mathrm{CH}$ oxidation pathway, which bypasses the formation of carbon from $\mathrm{CH}_{4}$. Furthermore, carbon formation from methane dissociation could decrease if the rate of $\mathrm{CH}$ oxidation exceeded that of $\mathrm{C}$ oxidation. In contrast, carbon formed from the $\mathrm{CO}_{2}$ dissociation pathway could be related to the energy barrier in $\mathrm{CO}$. First, $\mathrm{CO}_{2}$ dissociates on the catalyst into $\mathrm{CO}$ and $\mathrm{O}$. Then, $\mathrm{CO}$ dissociates into $\mathrm{C}$ and $\mathrm{O}$ and forming carbon. Thus, the high energy barrier of $\mathrm{CO}$ could prevent the formation of carbon.

Djaidja et al. [78] highlighted that the inhibition of carbon deposition over a $\mathrm{Ni}-\mathrm{M} / \mathrm{MgO}$ catalyst is a result of increasing the adsorption of $\mathrm{CO}_{2}$ on the support surface, enhancing the rate of surface reaction and decreasing the rate of methane decomposition. Meanwhile, Theofanidis et al. [28] stated that carbon deposition could be solved with a higher distribution of active metal on the support surface, high basicity of catalyst surface to 


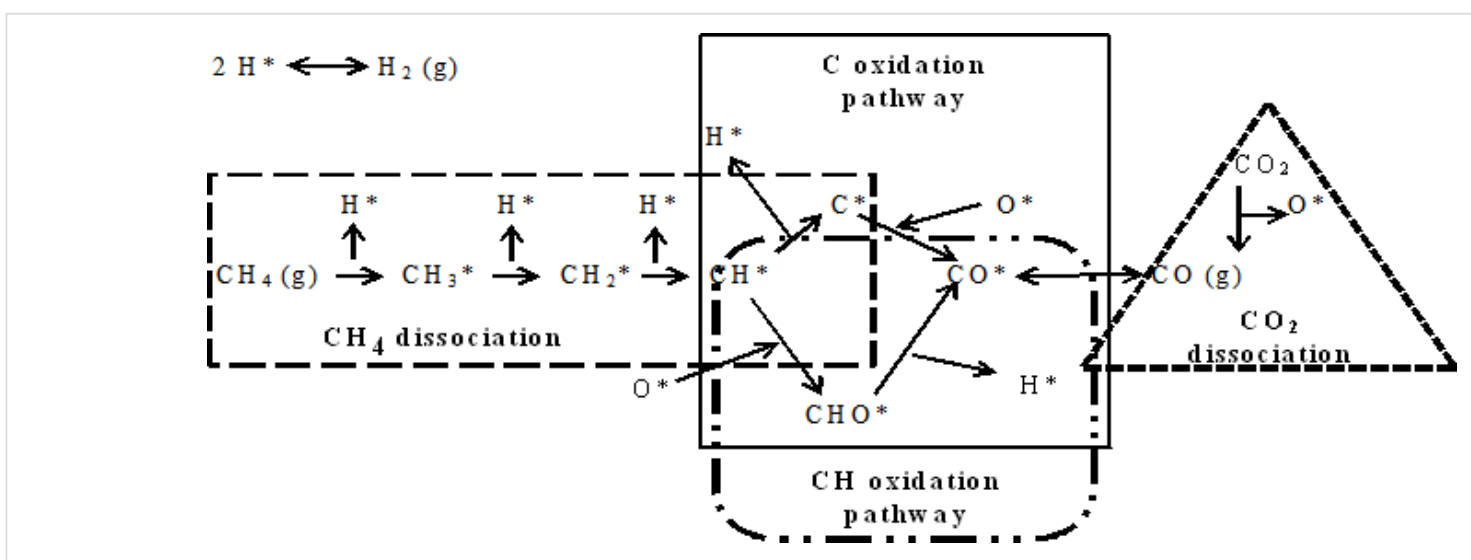

Figure 2: A schematic diagram of the DRM reaction on Ni metal. Adapted from [73].

capture acidic $\mathrm{CO}_{2}$, and the addition of resources that offer an oxygen atom through their redox properties.

Theofanidis et al. [28] proposed a mechanism for carbon removal using $\mathrm{Fe}-\mathrm{Ni} / \mathrm{MgAl}_{2} \mathrm{O}_{4}$ in a DRM reaction. They focused on the mechanism of carbon species removal by $\mathrm{CO}_{2}$. They proposed that the carbon removal mechanism involved two parallel processes, as clearly depicted in Figure 3a. First, $\mathrm{CO}_{2}$ was dissociated over $\mathrm{Ni}$ metal followed with the surface oxygen $\left(\mathrm{O}_{\mathrm{s}}\right)$ originating from $\mathrm{O}_{2}$ dissociation or by direct interaction with gas phase $\mathrm{O}_{2}$. Then, $\mathrm{O}_{\mathrm{s}}$ combined with the carbon deposited on the Ni metal $\left(\mathrm{C}_{\mathrm{m}}\right)$ to form $\mathrm{CO}$. The second process commenced with the oxidation of $\mathrm{Fe}$ by $\mathrm{CO}_{2}$ to form iron oxide $\left(\mathrm{Fe}_{3} \mathrm{O}_{4}\right)$. Next, the lattice oxygen $\left(\mathrm{O}_{\mathrm{L}}\right)$ obtained from the reduction of $\mathrm{Fe}_{3} \mathrm{O}_{4}$ was pooled with carbon deposited on the metal $\left(\mathrm{C}_{\mathrm{m}}\right)$ to form $\mathrm{CO}$. However, carbon located far from the active sites $\left(\mathrm{C}_{\mathrm{s}}\right)$ does not directly intermingle with $\mathrm{CO}_{2}$. Based on the results of this study, the application of $\mathrm{MgAl}_{2} \mathrm{O}_{4}$ as support could help the adsorption of more $\mathrm{CO}_{2}$ on the catalyst surface because of its alkaline property and consequently increase the rate of elimination of carbon deposited on the catalyst as a result of the dehydrogenation of $\mathrm{CH}_{4}$. Figure $3 \mathrm{~b}$ exhibits the proposed mechanisms of carbon removal by Khavarian et al.
[69], who demonstrated carbon removal by active surface oxygen produced from $\mathrm{CO}_{2}$ dissociation over active metal particles supported by multiwalled carbon nanotubes (MWCNTs). Interestingly, the active sites of the catalyst were regenerated, and stable conversions were accomplished. In brief, development of a reliable surface reaction mechanism is a complex process. However, there are various elementary mechanisms developed for the DRM reaction, which should be measured in the absence of heat and mass transfer limitations [29].

\section{Kinetic study in DRM}

Several research studies have investigated how to inhibit or remove carbon formation at the early stages. It is believed that the development of a coke-resistant catalyst may lie in a detailed understanding of catalytic processes and kinetic studies. The reaction kinetics in the DRM depends on the type of catalysts and the involvement of reactants in the reaction. Even though the type of catalyst, the nature of the support and the reaction temperature range affect the reaction kinetics in DRM, there is still no available universal expression for the reaction kinetics in this process. Many studies have been carried out especially on developing elementary and microkinetic analyses for the understanding of reactions that occur in DRM

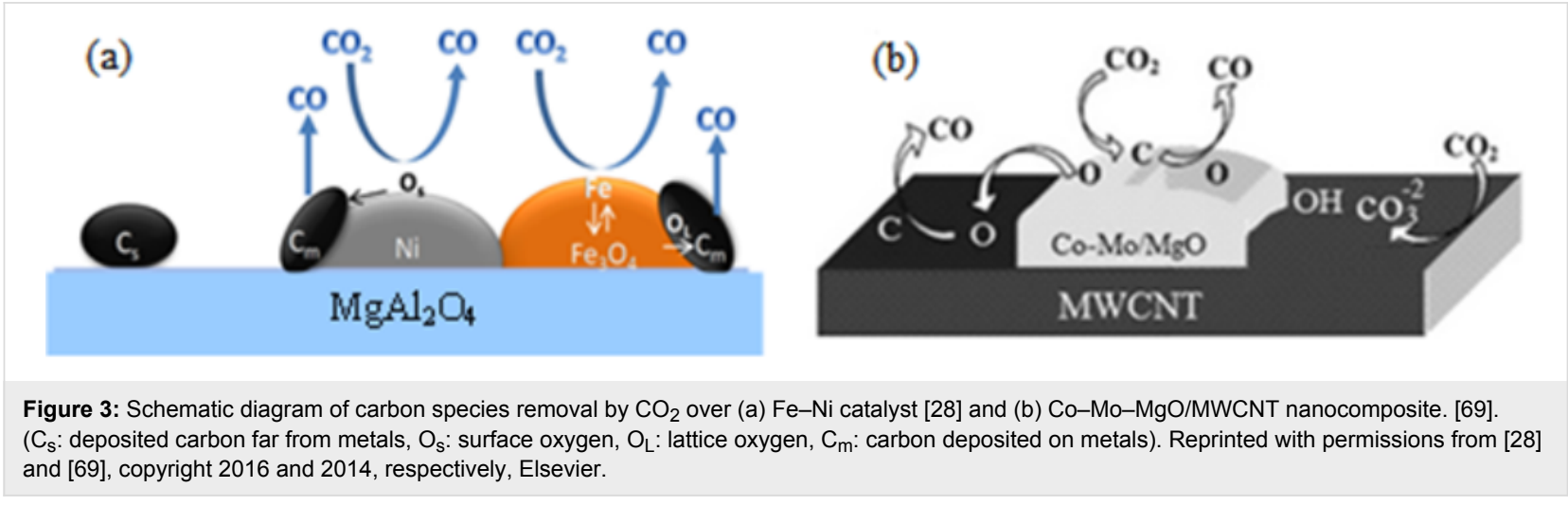


[79-82]. Microkinetic analysis is an investigation based on elementary chemical reactions on the catalytic surface and their relationship with each other and with the surface during a catalytic cycle. Commonly, the kinetic parameters involved in reactions are extracted from experimental and theoretical studies using several methods, which include adsorption, surface reaction and desorption [82].

Fan et al. [3] performed a kinetic study over $\mathrm{Ni}-\mathrm{Co} / \mathrm{MgO}-\mathrm{ZrO}_{2}$ at various partial pressures $(45-360 \mathrm{kPa})$ and temperatures (700-800 ${ }^{\circ} \mathrm{C}$ ). In this study, the effects of $\mathrm{CH}_{4}$ and $\mathrm{CO}_{2}$ partial pressure on the reforming rate were observed respectively. The results obtained emphasized that the partial pressure of $\mathrm{CO}_{2}$ showed a positive effect on the reforming rate compared to $\mathrm{CH}_{4}$, as shown clearly in Figure 4a,b. The authors declared that this is due to more $\mathrm{CO}_{2}$ being attracted and adsorbed to the surface of the catalyst, which has a higher basicity support and strong metal-support interaction compared to $\mathrm{CH}_{4}$.

Table 1 displays a comparison of the activation energies found in the literature using various catalysts for DRM [3]. The $\mathrm{CO}_{2}$ activation energy in this study recorded a lower value, which is $48.1 \mathrm{~kJ} / \mathrm{mol}$ compared to that of $\mathrm{CH}_{4}$ and $\mathrm{CO}_{2}$ of previous studies. This is might be due to the existence of $\mathrm{Mg}$, which is known to be a strong Lewis base, making it easier for $\mathrm{CO}_{2}$ to activate on the $\mathrm{Ni}-\mathrm{Co} / \mathrm{MgO}-\mathrm{ZrO}_{2}$ catalyst.

The effect of the presence of $\mathrm{MgO}$ in maintaining the stability of the catalyst was clearly exhibited in the X-ray photoelectron spectroscopy (XPS) results, as shown in Figure 5. Based on a study by Fan et al. [52], Figure 5 shows a high binding energy of $531.5 \mathrm{eV}$. This indicates the high intensity of the hydroxyl group by the $\mathrm{Ni}-\mathrm{Co} / \mathrm{MgO}-\mathrm{ZrO}_{2}$ catalyst, which reflects high surface basicity.

Kinetic studies of DRM over $\mathrm{Ni}-\mathrm{Co} / \mathrm{Al}-\mathrm{Mg}-\mathrm{O}$ have been carried out by Zhang et al. [86]. From this study, it was found that the rate of reforming is more prone to $\mathrm{CH}_{4}$ partial pressure rather than $\mathrm{CO}_{2}$ partial pressure, which is clearly displayed in Figure 6a,b. The authors mention that this might be due to a high amount of $\mathrm{CH}_{4}$ being adsorbed to the catalyst surface compared to $\mathrm{CO}_{2}$ at higher partial pressure.
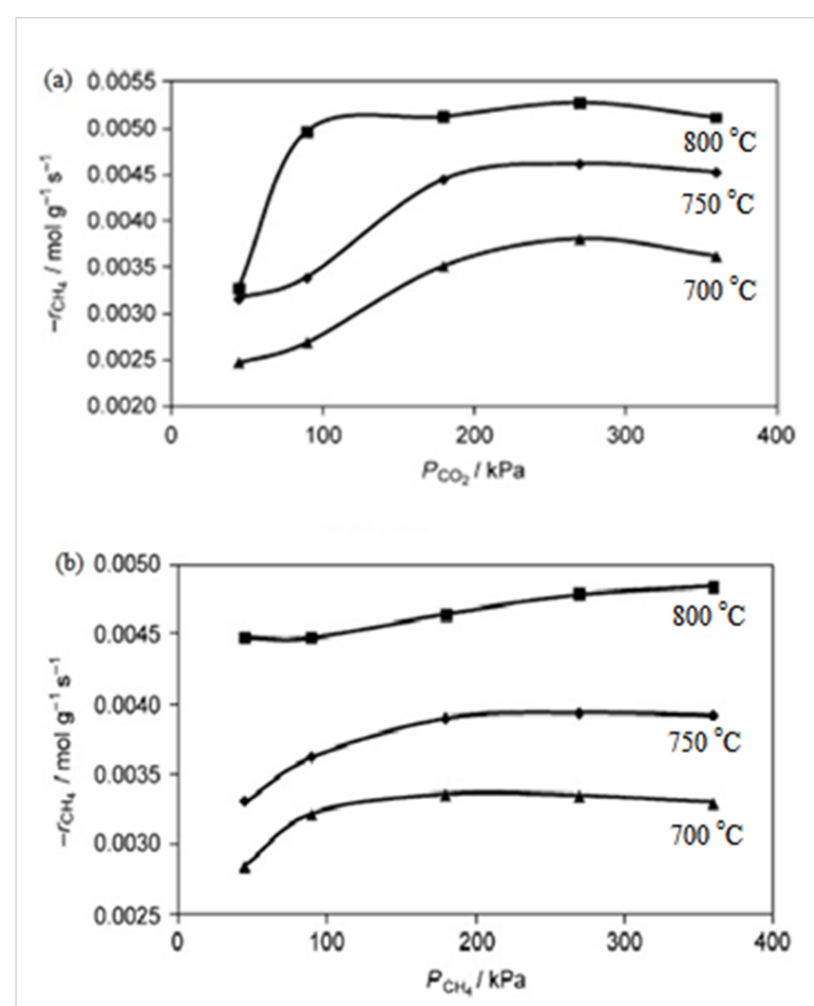

Figure 4: The partial pressure effect of (a) $\mathrm{CO}_{2}$ and (b) $\mathrm{CH}_{4}$ on the rate of $\mathrm{CH}_{4}$ reforming; $P_{\mathrm{CO} 2}=90 \mathrm{kPa}$. Reprinted with permission from [3], copyright 2011 Elsevier.

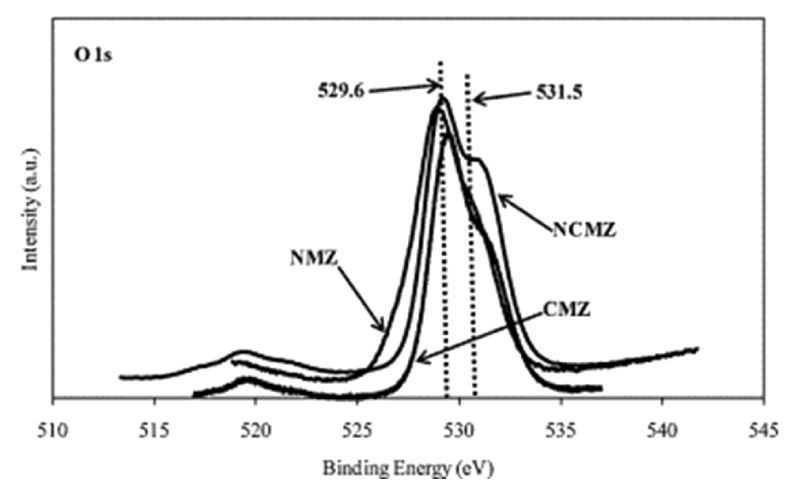

Figure 5: XPS spectra of $\mathrm{O} 1 \mathrm{~s}$ of the catalysts. (NCMZ $=\mathrm{Ni}-\mathrm{Co} /$ $\left.\mathrm{MgO}-\mathrm{ZrO}_{2}, \mathrm{NMZ}=\mathrm{Ni} / \mathrm{MgO}-\mathrm{ZrO}_{2}, \mathrm{CMZ}=\mathrm{Co} / \mathrm{MgO}-\mathrm{ZrO}_{2}\right)$. Reprinted with permission from [52], copyright 2010 Elsevier.

Table 1: Activation energies of various catalysts for DRM [3].

\begin{tabular}{llll} 
Catalyst & $T\left({ }^{\circ} \mathrm{C}\right)$ & Activation energy of $\mathrm{CH}_{4}(\mathrm{~kJ} / \mathrm{mol})$ & Activation energy of $\mathrm{CO}_{2}\left(\mathrm{~kJ} / \mathrm{mol}^{2}\right)$ \\
\hline $\mathrm{Ni}-\mathrm{Co} / \mathrm{MgO}-\mathrm{ZrO}_{2}$ & $700-800$ & 52.9 & 48.1 \\
$\mathrm{Ni} / \mathrm{Al} \mathrm{O}_{3}$ & $500-700$ & 50.9 & 56.1 \\
$\mathrm{Ni} / \mathrm{MgO}$ & $450-550$ & 92.1 & 87.9 \\
$\mathrm{Ni} / \mathrm{CaO}-\mathrm{Al}_{2} \mathrm{O}_{3}$ & $620-690$ & 106.8 & 98.8
\end{tabular}



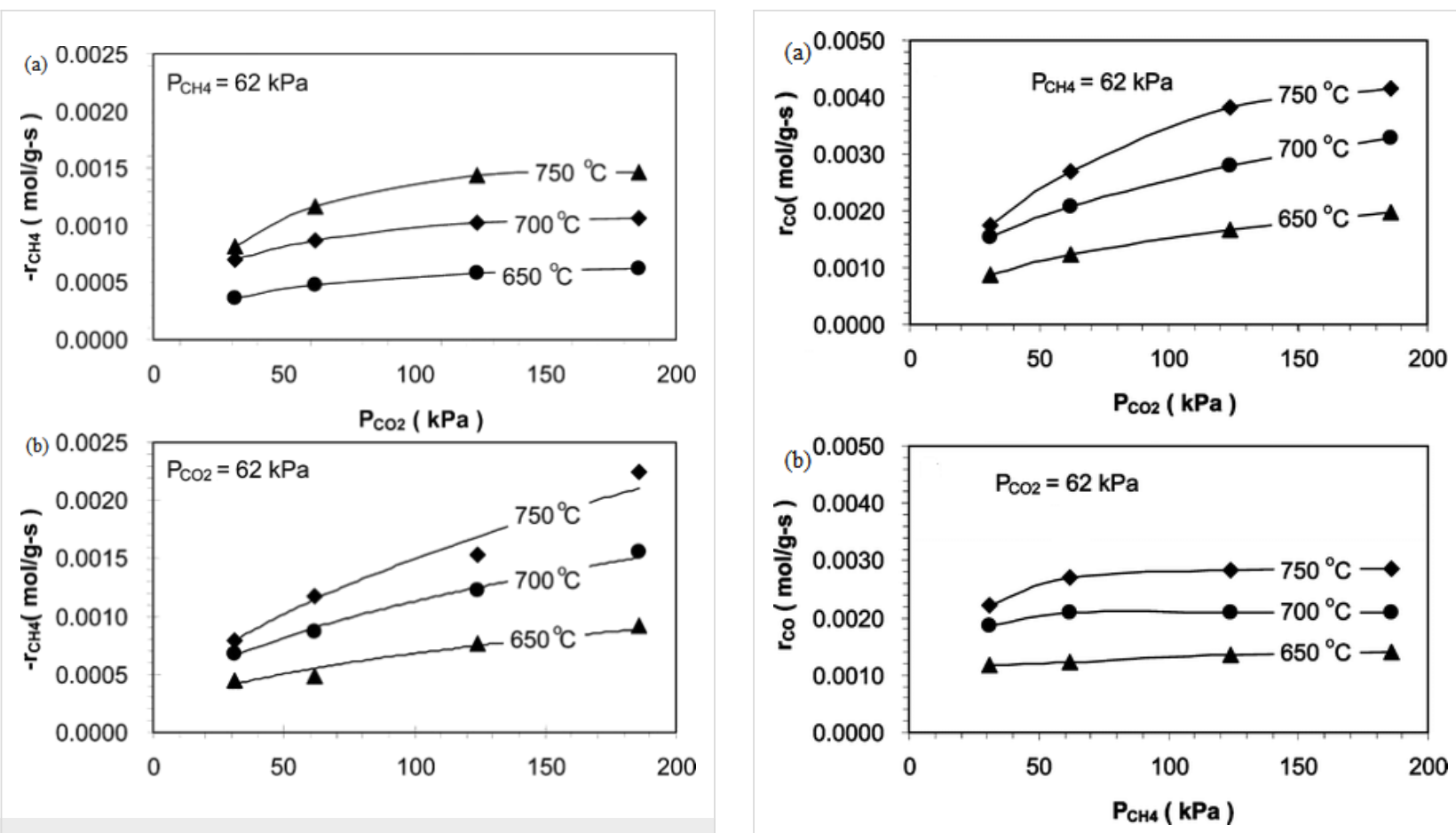

Figure 6: The reforming rates of DRM over the Ni-Co/Al-Mg-O catalyst affected by the (a) $\mathrm{CO}_{2}$ partial pressure and (b) $\mathrm{CH}_{4}$ partial pressure at different temperatures. Reprinted from [86], copyright 2009 American Chemical Society.

Zhang et al. [86] also studied the formation rate of products influenced by the partial pressure of the reactants. Figure $7 a, b$ shows that the rate of $\mathrm{CO}$ formation is more sensitive towards $\mathrm{CO}_{2}$ partial pressure compared to $\mathrm{CH}_{4}$ partial pressure. This could be attributed to the reverse water-gas shift (RWGS) reaction. Moreover, the $\mathrm{H}_{2}$ formation is relatively stable in both $\mathrm{CO}_{2}$ partial pressure and $\mathrm{CH}_{4}$ partial pressure due to the simultaneously occurrence of DRM and RWGS reactions. Figure 8a,b displays the effect of reactant partial pressure on $\mathrm{H}_{2}$ formation rates.

Table 2 outlines the values of activation energy for $\mathrm{CO}_{2}, \mathrm{CH}_{4}$, $\mathrm{H}_{2}$ and $\mathrm{CO}_{2}$ for various catalysts. The authors highlighted that the lowest activation energies were recorded by $\mathrm{CO}_{2}$. This is probably due to the existence of $\mathrm{MgO}$, which is a strong Lewis base that acts as a support in this study, and can also activate $\mathrm{CO}_{2}$. The activation energy of $\mathrm{H}_{2}$ is greater than $\mathrm{CO}$ because of the occurrence of the RWGS reaction.

\section{Development of Mg-containing oxide catalysts}

The use of $\mathrm{Mg}$ or $\mathrm{MgO}$, as either a promoter or a support in catalyst components, has attracted considerable interest [5052,78]. Catalyst supports and promoters perform different roles in chemical reactions. Catalyst supports are normally applied to increase the catalyst surface area for active metal dispersion and

Figure 7: The formation rates of $\mathrm{CO}$ affected by (a) $\mathrm{CH}_{4}$ partial pressure and (b) $\mathrm{CO}_{2}$ partial pressure at different temperatures. Reprinted from [86], copyright 2009 American Chemical Society.
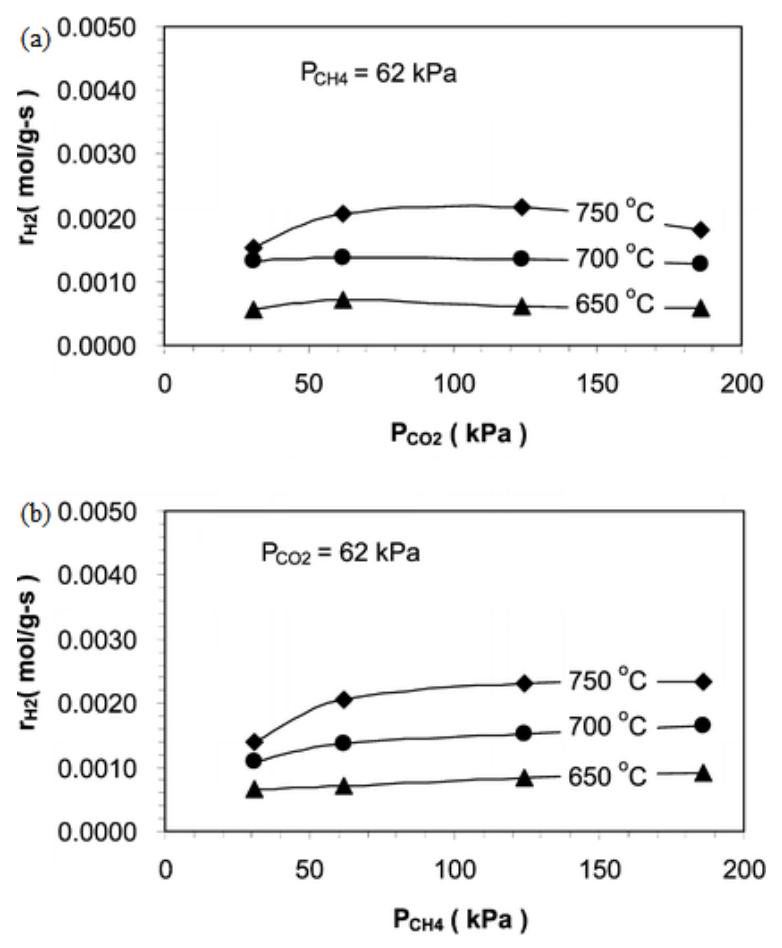

Figure 8: The formation rates of $\mathrm{H}_{2}$ affected by (a) $\mathrm{CH}_{4}$ partial pressure and (b) $\mathrm{CO}_{2}$ partial pressure at different temperatures. Reprinted from [86], copyright 2009 American Chemical Society. 


\begin{tabular}{|c|c|c|c|c|c|c|}
\hline Catalyst & $T\left({ }^{\circ} \mathrm{C}\right)$ & $\begin{array}{l}\text { Activation energy of } \\
\mathrm{CH}_{4}(\mathrm{~kJ} / \mathrm{mol})\end{array}$ & $\begin{array}{l}\text { Activation energy of } \\
\mathrm{CO}_{2}(\mathrm{~kJ} / \mathrm{mol})\end{array}$ & $\begin{array}{l}\text { Activation energy of } \\
\mathrm{CO}(\mathrm{kJ} / \mathrm{mol})\end{array}$ & $\begin{array}{l}\text { Activation energy of } \\
\mathrm{H}_{2}(\mathrm{~kJ} / \mathrm{mol})\end{array}$ & Ref. \\
\hline $\mathrm{Ni}-\mathrm{Co} / \mathrm{Al}-\mathrm{Mg}-\mathrm{O}$ & $650-750$ & 69.4 & 25.9 & 61.8 & 85.1 & [86] \\
\hline $\mathrm{Ni} / \mathrm{Al}_{2} \mathrm{O}_{3}$ & $500-700$ & 50.9 & 56.1 & 80.5 & - & [83] \\
\hline $\mathrm{Ni} / \mathrm{CaO}-\mathrm{Al}_{2} \mathrm{O}_{3}$ & $620-690$ & 106.8 & 98.8 & 103 & 147.4 & [85] \\
\hline
\end{tabular}

to enhance the properties of the catalyst $[65,87,88]$. However, supports sometimes act as a transportation medium for the active sites while remaining catalytically inactive during the reaction [65]. Park and Song [89] stated that conventional supports could stabilize active metal and prevent the occurrence of leaching or metal agglomeration. The authors further mention that supports can not only transport the reactants to the reaction center, but can also control diffusion rates of reactants and products and donate protons or electrons to alter total reactivity. Promoters can be classified as small amounts of additives to active metals or support. The promoter of supports is used to prevent unwanted catalyst activity, such as carbon deposition, while promoters are added to active components to enhance reaction activity [90].

The activity and stability of catalysts prepared by various preparation methods have been observed by numerous researchers [91-94]. The catalyst preparation technique is an alternative approach to achieve carbon inhibition by controlling particle size and metal loading during catalyst preparation. The pivotal factors determining the activity and the selectivity of the catalysts are the dispersion and the physico-chemical characteristics of active metals on the support catalyst. Three general approaches are applied for the catalyst preparation, including (i) deposition of active metals onto a support; (ii) precipitation of materials with significant properties; and (iii) preparation of compact, nonporous compounds, or alloys with an active component, followed by the extraction of inactive particles, leaving a porous, high-surface-area active phase [95]. Arora [96] further highlighted that strong metal-support interactions were observed at low metal loadings $(<12 \%)$, and a small particle size $(<6 \mathrm{~nm}$ ) could prevent carbon accumulation on the catalyst surface. The effects of operating conditions were investigated by adjusting the reaction temperature, feed ratio, space velocity, and temperature. The following sections investigate the influence of these variables on catalytic activity and morphology of deposited carbon. The target product compositions are also outlined.

\section{Application of $\mathrm{MgO}$ as a support}

Djaidja et al. [78] prepared a $\mathrm{Ni} / \mathrm{MgO}$ catalyst via an impregnation method to test the performance in a DRM reaction. The conversion of $\mathrm{CO}_{2}$ and $\mathrm{CH}_{4}$ with $\mathrm{MgO}$ using $5 \mathrm{~mol} \%$ of $\mathrm{Ni}$ loading were $98.1 \%$ and $97.1 \%$, respectively, and a $\mathrm{H}_{2} / \mathrm{CO}$ ratio of 1.1 was recorded with a low quantity of deposited carbon. Notably, a slightly higher coke deposition was recorded in the catalyst without Mg. Thus, this finding proves that coke could be minimized with an increase in $\mathrm{MgO}$ concentration in the catalyst because $\mathrm{MgO}$ exhibits alkaline characteristics. Its high basicity and similar crystal structure with $\mathrm{NiO}$ render $\mathrm{MgO}$ as highly suitable for Ni-based catalyst supports. Strong metal-support interaction between $\mathrm{MgO}$ and $\mathrm{NiO}$ formed a basic solid solution $\left(\mathrm{Ni}_{x} \mathrm{Mg}_{(1-x)} \mathrm{O}\right)$ and could consequently enhance $\mathrm{CO}_{2}$ adsorption and $\mathrm{Ni}$ particle size. Moreover, the reduced $\mathrm{Ni} / \mathrm{MgO}$ catalysts may result in a high distribution of Ni particles and may prevent the occurrence of particle sintering during DRM reactions. Therefore, this catalyst exhibits the potential for long-term reaction and resistance to carbon formation. As highlighted, $15 \mathrm{wt} \%$ of Ni metal loading is required for substantial metal-support interaction and high catalytic activity in DRM [97].

Hua et al. [36] synthesized a $\mathrm{Ni} / \mathrm{MgO}$ catalyst via a dielectric barrier discharge plasma and compared the catalyst with the ones prepared via the conventional impregnation method. The $\mathrm{Ni} / \mathrm{MgO}$ catalyst prepared using a dielectric barrier discharge plasma presented a smaller particle size, higher dispersion, and higher specific surface area. Moreover, the recorded $\mathrm{CO}_{2}$ and $\mathrm{CH}_{4}$ conversions were $20 \%$ higher than that of the conventionally prepared catalyst. The plasma treatment method is suggested to be more appropriate for the preparation of $\mathrm{Ni} / \mathrm{MgO}$, offering high activity and stability, and a lesser amount of deposited carbon on the catalyst compared to using the $\mathrm{Ni} / \mathrm{MgO}$ catalyst prepared via impregnation. Zanganeh et al. [34] used the co-precipitation method to prepare a $\mathrm{NiO}-\mathrm{MgO}$ nanocrystalline solid solution catalyst. High Ni (25 wt \%) content negatively affected the supression of carbon deposition on the solid solution catalyst. However, high Ni dispersion and the basicity of the support surface could inhibit carbon formation in DRM on the reduced $\mathrm{Ni}_{0.03} \mathrm{Mg}_{0.97} \mathrm{O}$ solid solution catalyst.

DBD plasma, also known as silent discharge, is a conventional cold plasma phenomenon that has been widely applied in the preparation of multi-oxide catalysts. This method can over- 
come the problem that arises from the use of thermal calcination techniques at high temperature. This plasma treatment is the most well-known technique because of its requirement for a low operation temperature with greatly energetic electrons for catalyst preparation. Thus, this method is very friendly towards heat sensitive substrates. Rapid reactions occur between the active plasma species and catalyst precursors compared to the thermal decomposition technique. Therefore, this may encourage the rapid nucleation of the crystals under plasma treatment. The application of low temperature may result in slow crystal growth, which contributes to the production of a catalyst with a small particle size or high metal dispersion. Furthermore, plasma treatment has been proven to show superb performance in surface treatment and modification. Moreover, this technique is able to efficiently decompose precursors at low temperature. Greater dispersion of oxide nanoparticles on another oxide support can be obtained via plasma treatment without any additional chemicals. [98]

According to previous studies $[36,99,100]$, plasma-treated catalysts have a smaller particle size, enhanced metal dispersion and increased specific surface area. Moreover, Yan et al. [101] confirmed that plasma treated catalysts can improve the interaction between $\mathrm{Ni}$ and the $\mathrm{SiO}_{2}$ support and produces less defect sites on the Ni particles. The authors further remarked that this plasma treatment could suppress inactive carbon deposition and enhance catalyst performance. Yan et. al [102] studied the preparation methods of the Ni catalyst, which are the DBD plasma and thermal decomposition. It is interesting to note that plasma treatment produces more Ni (111) surface with fewer defects, which is most suitable for suppressing carbon deposition. Meanwhile, the structure for Ni catalysts were treated via thermal decomposition recorded with a great number of defect sites, which consist of $\mathrm{Ni}(100)$ and $\mathrm{Ni}$ (101) surfaces. These surfaces could increase carbon deposition rate. Table 3 summarizes the development and process conditions of $\mathrm{Mg}$-containing oxide catalysts used in DRM.

\section{Application of $\mathrm{MgO}$ as a co-support}

Abdollahifar et al. [49] investigated catalyst performance by applying the ultrasound-assisted impregnation (sonochemistry) method in the synthesis of a Ni/ $\mathrm{Al}_{2} \mathrm{O}_{3}-\mathrm{MgO}$ catalyst for a $\mathrm{DRM}$ reaction. The measured surface area for the $\mathrm{Ni} /$ $\mathrm{Al}_{2} \mathrm{O}_{3}-\mathrm{MgO}$ catalyst was $53.25 \mathrm{~m}^{2} / \mathrm{g}$. Ni nanoparticles with a diameter of $21.4 \mathrm{~nm}$ were dispersed on the support. For the catalyst performance, at a reaction temperature range of $750{ }^{\circ} \mathrm{C}$ to $800{ }^{\circ} \mathrm{C}$ was used and $\mathrm{CO}_{2}$ conversion and $\mathrm{H}_{2} / \mathrm{CO}$ ratios almost achieved thermodynamic equilibrium. At the reaction temperature range of $500{ }^{\circ} \mathrm{C}$ to $800{ }^{\circ} \mathrm{C}$, the recorded $\mathrm{CO}_{2}$ is markedly higher than $\mathrm{CH}_{4}$ conversion and the $\mathrm{H}_{2} / \mathrm{CO}$ ratio reaches unity. The $\mathrm{Ni} / \mathrm{Al}_{2} \mathrm{O}_{3}-\mathrm{MgO}$ catalyst was stable without deactivation for up to $53 \mathrm{~h}$ at a reaction temperature of $700{ }^{\circ} \mathrm{C}$.

\begin{tabular}{|c|c|c|c|c|c|c|c|c|c|}
\hline \multirow[t]{2}{*}{ Catalyst } & \multirow[t]{2}{*}{ PM } & \multirow[t]{2}{*}{ W (wt \%) } & \multirow[t]{2}{*}{$\mathrm{CC}$} & \multirow[t]{2}{*}{$\mathrm{RC}$} & \multicolumn{5}{|c|}{ Conversion } \\
\hline & & & & & $\begin{array}{l}\mathrm{CH}_{4} \\
(\%)\end{array}$ & $\begin{array}{l}\mathrm{CO}_{2} \\
(\%)\end{array}$ & $\mathrm{H}_{2} / \mathrm{CO}$ & Carbon & Ref. \\
\hline $\mathrm{Ni}-\mathrm{Ce} / \mathrm{Mg}-\mathrm{Al}$ & $\begin{array}{l}\text { carbonate } \\
\text { co- } \\
\text { precipitation }\end{array}$ & $\mathrm{Ni} / \mathrm{Mg}: 2 / 1^{\mathrm{a}}$ & $\begin{array}{l}T=500{ }^{\circ} \mathrm{C} \\
t=16 \mathrm{~h}\end{array}$ & $\begin{array}{l}T=500- \\
800^{\circ} \mathrm{C} \\
\mathrm{CH}_{4} / \mathrm{CO}_{2} 1: 1^{\mathrm{a}} \\
\mathrm{SV}=30 \mathrm{~L} / \mathrm{h} \cdot \mathrm{g}\end{array}$ & 90 & 95 & $\begin{array}{l}1.2- \\
1.5\end{array}$ & - & {$[50]$} \\
\hline $\mathrm{Ni} / \mathrm{MgO}$ & impregnation & $\begin{array}{l}\mathrm{Ni}: \\
5-10 \text { wt \% }\end{array}$ & $\begin{array}{l}T=600- \\
900{ }^{\circ} \mathrm{C}\end{array}$ & $\begin{array}{l}T=800{ }^{\circ} \mathrm{C} \\
\mathrm{CH}_{4} / \mathrm{CO}_{2} 1: 1^{\mathrm{a}}\end{array}$ & 97.15 & 98.1 & 1.1 & - & [78] \\
\hline $\mathrm{Ni} / \mathrm{MgO}$ & $\begin{array}{l}\text { dielectric } \\
\text { barrier } \\
\text { discharge } \\
\text { plasma }\end{array}$ & Ni: 10 wt $\%$ & $\begin{array}{l}T=700{ }^{\circ} \mathrm{C} \\
t=4 \mathrm{~h}\end{array}$ & $\begin{array}{l}P=1 \mathrm{~atm}, \\
T=700{ }^{\circ} \mathrm{C}, \\
\mathrm{CH}_{4} / \mathrm{CO}_{2} / \mathrm{NO}_{2} \\
1: 1: 2^{\mathrm{a}}, \\
\mathrm{SV}=96 \mathrm{~L} / \mathrm{h} \cdot \mathrm{g}\end{array}$ & 46 & 52 & 0.84 & 3.9 wt $\%$ & {$[36]$} \\
\hline $\begin{array}{l}\text { Pt-Ni-Mg/ } \\
\text { Ceria-zirconia }\end{array}$ & $\begin{array}{l}\text { co- } \\
\text { precipitation; } \\
\text { incipient } \\
\text { wetness } \\
\text { impregnation }\end{array}$ & $\begin{array}{l}\mathrm{Pt} / \mathrm{Ni} / \mathrm{Mg}: \\
(0.2-2) / 8 / 8 \\
\text { wt } \%\end{array}$ & $\begin{array}{l}T=800{ }^{\circ} \mathrm{C} \\
t=4 \mathrm{~h}\end{array}$ & $\begin{array}{l}P=1 \mathrm{~atm} \\
T=430- \\
470^{\circ} \mathrm{C} \\
\mathrm{CH}_{4} / \mathrm{CO}_{2} 1: 1^{\mathrm{a}} \\
\mathrm{SV}=68,000 \mathrm{~h}^{-1}\end{array}$ & $\approx 10$ & $\approx 20$ & 0.23 & $\begin{array}{l}\text { no coke } \\
\text { deposited }\end{array}$ & {$[51]$} \\
\hline $\begin{array}{l}\mathrm{Ni}-\mathrm{Co} / \\
\mathrm{MgO}-\mathrm{ZrO}_{2}\end{array}$ & $\begin{array}{l}\text { surfactant- } \\
\text { assisted } \\
\text { impregnation; } \\
\text { impregnation }\end{array}$ & $\begin{array}{l}\text { Ni: } 3 \\
\text { Co: } 3 \text { wt \% }\end{array}$ & $\begin{array}{l}T=800{ }^{\circ} \mathrm{C} \\
t=3 \mathrm{~h}\end{array}$ & $\begin{array}{l}P=1 \mathrm{~atm} \\
T=750^{\circ} \mathrm{C} \\
\mathrm{CH}_{4} / \mathrm{CO}_{2} 1: 1^{\mathrm{a}} \\
\mathrm{SV}=125 \mathrm{~L} / \mathrm{h} \cdot \mathrm{g}\end{array}$ & 80 & 84 & 0.97 & $\begin{array}{l}0.89 \\
\mathrm{mg} / \mathrm{g}_{\text {catalyst }}\end{array}$ & {$[52]$} \\
\hline
\end{tabular}




\begin{tabular}{|c|c|c|c|c|c|c|c|c|c|}
\hline $\mathrm{Ni} / \mathrm{ZrO}_{2}-\mathrm{MgO}$ & $\begin{array}{l}\text { co- } \\
\text { precipitation; } \\
\text { wet } \\
\text { impregnation }\end{array}$ & $\begin{array}{l}\mathrm{MgO}: \\
1-5 \text { wt } \%\end{array}$ & $\begin{array}{l}T=700^{\circ} \mathrm{C}, \\
t=3 \mathrm{~h}, \\
\text { rate }= \\
5^{\circ} \mathrm{C} / \mathrm{min}\end{array}$ & $\begin{array}{l}P=1 \mathrm{~atm} \\
T=600{ }^{\circ} \mathrm{C} \\
\mathrm{CH}_{4} / \mathrm{CO}_{2} 1: 1^{\mathrm{a}}\end{array}$ & 30 & 32 & - & $\begin{array}{l}0.26-0.31 \\
\mathrm{mg} / \mathrm{mg}_{\text {catalyst }}\end{array}$ & [103] \\
\hline $\mathrm{Ni}-\mathrm{Mg} / \mathrm{Al}_{2} \mathrm{O}_{3}$ & $\begin{array}{l}\text { reverse } \\
\text { microemulsion }\end{array}$ & $\begin{array}{l}\mathrm{Ni} / \mathrm{Mg}: \\
10^{\mathrm{a}}\end{array}$ & $\begin{array}{l}T=800^{\circ} \mathrm{C}, \\
t=2 \mathrm{~h} \\
\text { rate }= \\
10^{\circ} \mathrm{C} / \mathrm{min}\end{array}$ & $\begin{array}{l}P=1 \mathrm{~atm}, \\
T=400- \\
700^{\circ} \mathrm{C}, \\
\mathrm{CH}_{4} / \mathrm{CO}_{2} / \mathrm{He} \\
20: 20: 60^{\mathrm{a}}, \\
\mathrm{SV}=6,000 \mathrm{~h}^{-1}\end{array}$ & 58 & 69 & 0.67 & 0.5 wt $\%$ & [19] \\
\hline $\mathrm{Ni} / \mathrm{Al}_{2} \mathrm{O}_{3}-\mathrm{MgO}$ & sol-gel & $\mathrm{Ni}: 10 \mathrm{wt} \%$ & $\begin{array}{l}T=600{ }^{\circ} \mathrm{C} \\
t=5 \mathrm{~h}\end{array}$ & $\begin{array}{l}P=1 \mathrm{~atm}, \\
T=550- \\
850^{\circ} \mathrm{C}, \\
\mathrm{CH}_{4} / \mathrm{CO}_{2} \\
0.5-2.0^{\mathrm{a}}, \\
\mathrm{SV}=24- \\
60 \mathrm{~L} / \mathrm{h} \cdot \mathrm{g}\end{array}$ & $\begin{array}{l}93- \\
95\end{array}$ & $\begin{array}{l}97- \\
99\end{array}$ & $\begin{array}{l}0.5- \\
0.98\end{array}$ & - & [37] \\
\hline $\mathrm{Ni} / \mathrm{Al}_{2} \mathrm{O}_{3}-\mathrm{MgO}$ & impregnation & $\mathrm{Ni}: 10$ wt $\%$ & $\begin{array}{l}T=500{ }^{\circ} \mathrm{C} \\
t=2 \mathrm{~h}\end{array}$ & $\begin{array}{l}P=1 \mathrm{~atm}, \\
T=550- \\
850{ }^{\circ} \mathrm{C} \\
\mathrm{CH}_{4} / \mathrm{CO}_{2} \\
0.5-2.0^{\mathrm{a}} \\
\mathrm{SV}=24- \\
60 \mathrm{~L} / \mathrm{h} \cdot \mathrm{g}\end{array}$ & $\begin{array}{l}83- \\
85\end{array}$ & $\begin{array}{l}85- \\
87\end{array}$ & $\begin{array}{l}0.38- \\
0.78\end{array}$ & - & [37] \\
\hline $\mathrm{Ni}-\mathrm{MgO}-\mathrm{Al}_{2} \mathrm{O}_{3}$ & sol-gel & $\begin{array}{l}\mathrm{Ni}: 15 \text { wt \%, } \\
\mathrm{MgO} /(\mathrm{MgO}+ \\
\left.\mathrm{Al}_{2} \mathrm{O}_{3}\right) 0-1^{\mathrm{a}} \\
\text { optimum } \\
\text { ratio } \\
0.44-0.86^{\mathrm{a}}\end{array}$ & $\begin{array}{l}T=750^{\circ} \mathrm{C} \\
t=5 \mathrm{~h}\end{array}$ & $\begin{array}{l}P=1 \mathrm{~atm}, \\
T=800^{\circ} \mathrm{C}, \\
t=40 \mathrm{~h}, \\
\mathrm{CH}_{4}: \mathrm{CO}_{2}: \mathrm{N}_{2} \\
1: 1: 1^{\mathrm{a}} \\
\mathrm{SV}=36 \\
\mathrm{~L}_{\mathrm{CH} 4} / \mathrm{h} \cdot \mathrm{g}\end{array}$ & $\begin{array}{l}83.6- \\
90\end{array}$ & $\begin{array}{l}88.8- \\
92\end{array}$ & - & 13 wt $\%$ & [104] \\
\hline $\mathrm{Ni}-\mathrm{MgO}-\mathrm{Al}_{2} \mathrm{O}_{3}$ & $\begin{array}{l}\text { co- } \\
\text { precipitation }\end{array}$ & $\begin{array}{l}\mathrm{Ni}: 15 \mathrm{wt} \% \text {, } \\
\mathrm{MgO} /(\mathrm{MgO}+ \\
\left.\mathrm{Al}_{2} \mathrm{O}_{3}\right) 0-1^{\mathrm{a}} \\
\text { optimum } \\
\text { ratio } \\
0.44-0.86^{\mathrm{a}}\end{array}$ & $\begin{array}{l}T=750^{\circ} \mathrm{C} \\
t=5 \mathrm{~h}\end{array}$ & $\begin{array}{l}P=1 \mathrm{~atm}, \\
T=800{ }^{\circ} \mathrm{C}, \\
t=40 \mathrm{~h}, \\
\mathrm{CH}_{4}: \mathrm{CO}_{2}: \mathrm{N}_{2} \\
1: 1: 1 \mathrm{a} \\
\mathrm{SV}=36 \\
\mathrm{~L}_{\mathrm{CH} 4} / \mathrm{h} \cdot \mathrm{g}\end{array}$ & 83.6 & 88.8 & - & - & [104] \\
\hline $\mathrm{Ni}-\mathrm{Mg} / \mathrm{SiO}_{2}$ & impregnation & $\begin{array}{l}\text { Ni: } 10 \text { wt \%, } \\
\text { Mg: } 5 \text { wt \% }\end{array}$ & $\begin{array}{l}T=800^{\circ} \mathrm{C} \\
t=5 \mathrm{~h}\end{array}$ & $\begin{array}{l}P=1 \mathrm{~atm} \\
T=800^{\circ} \mathrm{C} \\
t=10 \mathrm{~h}, \\
\mathrm{CH}_{4} / \mathrm{CO}_{2} 1: 1^{\mathrm{a}}\end{array}$ & 74.6 & 78.6 & 1.49 & 6.56 wt \% & [105] \\
\hline $\mathrm{Ni} / \mathrm{MgO} / \mathrm{Y}-\mathrm{Al}_{2} \mathrm{O}_{3}$ & cold plasma & $\begin{array}{l}\mathrm{Ni}: 12 \text { wt } \% \\
\text { MgO: } 2 \text { wt \% }\end{array}$ & $\begin{array}{l}T=550^{\circ} \mathrm{C} \\
t=4 \mathrm{~h}\end{array}$ & $\begin{array}{l}P=1 \mathrm{~atm}, \\
T=800^{\circ} \mathrm{C}, \\
t=400 \mathrm{~h}, \\
\mathrm{CH}_{4} / \mathrm{CO}_{2} 4: 6^{\mathrm{a}}, \\
\mathrm{SV}=30 \mathrm{~L} / \mathrm{h} \cdot \mathrm{g}\end{array}$ & $\begin{array}{l}78- \\
97\end{array}$ & 74 & - & 5 wt \% & [106] \\
\hline $\mathrm{NiO} / \mathrm{MgO}$ & impregnation & $\begin{array}{l}\mathrm{NiO} / \mathrm{MgO} \\
20: 100^{\mathrm{b}}\end{array}$ & $\begin{array}{l}T=600- \\
800^{\circ} \mathrm{C} \\
t=1.5 \mathrm{~h}\end{array}$ & $\begin{array}{l}P=0.1 \mathrm{MPa}, \\
T=800{ }^{\circ} \mathrm{C} \\
t=5 \mathrm{~h}, \\
\mathrm{CH}_{4} / \mathrm{CO}_{2} 1: 1^{\mathrm{a}}, \\
\mathrm{SV}=20 \mathrm{~L} / \mathrm{h} \cdot \mathrm{g}\end{array}$ & $\begin{array}{l}85- \\
92\end{array}$ & $\begin{array}{l}90- \\
94\end{array}$ & - & - & [94] \\
\hline $\mathrm{Ni}-\mathrm{Mg}-\mathrm{Al}$ & $\begin{array}{l}\text { co- } \\
\text { precipitation }\end{array}$ & $\mathrm{Ni} / \mathrm{Mg} 1-5^{\mathrm{a}}$ & $\begin{array}{l}T=400- \\
800^{\circ} \mathrm{C} \\
t=6 \mathrm{~h}\end{array}$ & $\begin{array}{l}P=1 \mathrm{~atm}, \\
T=700^{\circ} \mathrm{C}, \\
\mathrm{CH}_{4} / \mathrm{CO}_{2} / \mathrm{N}_{2} \\
1: 2: 9^{\mathrm{a}}, \\
\mathrm{SV}=45 \mathrm{~L} / \mathrm{h} \cdot \mathrm{g}\end{array}$ & $\begin{array}{l}95- \\
96\end{array}$ & $\begin{array}{l}49- \\
50\end{array}$ & - & $2.8-3.7$ wt \% & [92] \\
\hline $\mathrm{Ni} / \mathrm{MgO}$ & $\begin{array}{l}\text { wet } \\
\text { impregnation }\end{array}$ & Ni: 8.8 wt \% & $\begin{array}{l}T=400- \\
950^{\circ} \mathrm{C} \\
t=5 \mathrm{~h}\end{array}$ & $\begin{array}{l}P=0.1 \mathrm{MPa} \\
T=750{ }^{\circ} \mathrm{C} \\
\mathrm{CH}_{4} / \mathrm{CO}_{2} 1: 1^{\mathrm{a}}, \\
\mathrm{SV}=16- \\
240 \mathrm{~L} / \mathrm{h} \cdot \mathrm{g}\end{array}$ & 84 & - & - & - & [23] \\
\hline
\end{tabular}


Table 3: Literature summary on the development and process conditions of Mg-containing oxide catalysts in DRM. PM: Preparation method; W: metal loading; CC: calcination conditions; RC: reaction conditions; SV: space velocity. (continued)

\begin{tabular}{|c|c|c|c|c|c|c|c|c|c|}
\hline La-NiMgAl & $\begin{array}{l}\text { co- } \\
\text { precipitation }\end{array}$ & $\begin{array}{l}\mathrm{Ni}: 2.1 \mathrm{wt} \% \\
\mathrm{Mg} / \mathrm{Al} 1.7^{\mathrm{a}}\end{array}$ & $\begin{array}{l}T=250- \\
750{ }^{\circ} \mathrm{C} \\
t=2 \mathrm{~h}\end{array}$ & $\begin{array}{l}T=700^{\circ} \mathrm{C}, \\
t=50 \mathrm{~h}, \\
\mathrm{CH}_{4} / \mathrm{CO}_{2} 1: 1^{\mathrm{a}}\end{array}$ & $\begin{array}{l}25- \\
31\end{array}$ & $\begin{array}{l}32.5- \\
55\end{array}$ & - & $\begin{array}{l}0-0.06 \\
g_{c} / g_{\text {catalyst }} \cdot h\end{array}$ & [107] \\
\hline $\mathrm{NiCoMg} / \mathrm{Al}_{2} \mathrm{O}_{3}$ & $\begin{array}{l}\text { co- } \\
\text { impregnation }\end{array}$ & $\begin{array}{l}\mathrm{Ni}: 3, \mathrm{Co}: 3, \\
\mathrm{Mg}: 3 \text { wt } \%\end{array}$ & $\begin{array}{l}T=500{ }^{\circ} \mathrm{C} \\
t=5 \mathrm{~h}\end{array}$ & $\begin{array}{l}P=1 \mathrm{~atm} \\
T=850{ }^{\circ} \mathrm{C} \\
t=3000 \mathrm{~h} \\
\mathrm{CH}_{4} / \mathrm{CO}_{2} / \mathrm{N}_{2} \\
1: 1: 1^{\mathrm{a}} \\
\mathrm{SV}=80,000 \mathrm{~h}^{-1}\end{array}$ & 95.1 & 96.2 & 0.982 & 1.3 wt $\%$ & {$[54]$} \\
\hline $\mathrm{Ni} / \mathrm{MgO}$ & $\begin{array}{l}\text { wetness } \\
\text { impregnation }\end{array}$ & $\begin{array}{l}\text { Ni: } \\
5-15 \text { wt \% } \\
\text { Optimum } \\
15 \text { wt \% }\end{array}$ & $\begin{array}{l}T=500{ }^{\circ} \mathrm{C}, \\
t=4 \mathrm{~h}\end{array}$ & $\begin{array}{l}P=1 \mathrm{~atm}, \\
T=500- \\
700{ }^{\circ} \mathrm{C} \\
t=5 \mathrm{~h} \\
\mathrm{CH}_{4} / \mathrm{CO}_{2} \\
2: 1-1: 2^{\mathrm{a}} \\
\mathrm{SV}=6- \\
24 \mathrm{~L} / \mathrm{h} \cdot \mathrm{g}\end{array}$ & $\begin{array}{l}25- \\
86.29\end{array}$ & $\begin{array}{l}27- \\
86.77\end{array}$ & $\begin{array}{l}0.64- \\
0.91\end{array}$ & - & [108] \\
\hline $\mathrm{Ni} / \mathrm{MgO}$ (111) & impregnation & $\begin{array}{l}\mathrm{Ni}: \\
2-20 \text { wt \% }\end{array}$ & $\begin{array}{l}T=650{ }^{\circ} \mathrm{C} \\
t=5 \mathrm{~h}\end{array}$ & $\begin{array}{l}P=1 \mathrm{~atm}, \\
T=450- \\
650{ }^{\circ} \mathrm{C}, \\
t=10 \mathrm{~h}, \\
\mathrm{CH}_{4} / \mathrm{CO}_{2} 1: 1^{\mathrm{a}}, \\
\mathrm{SV}=36 \mathrm{~L} / \mathrm{h} \cdot \mathrm{g}\end{array}$ & $\begin{array}{l}28- \\
60\end{array}$ & $\begin{array}{l}40- \\
65\end{array}$ & - & - & [109] \\
\hline $\mathrm{Ni}-\mathrm{CeO}_{2} / \mathrm{MgO}$ & $\begin{array}{l}\text { surfactant- } \\
\text { assisted } \\
\text { precipitation }\end{array}$ & $\begin{array}{l}\mathrm{Ni}: \\
5-15 \text { wt \% } \\
\text { optimum } \\
10 \text { wt } \%\end{array}$ & $\begin{array}{l}T=500{ }^{\circ} \mathrm{C} \\
t=4 \mathrm{~h}\end{array}$ & $\begin{array}{l}P=1 \mathrm{~atm} \\
T=550- \\
700{ }^{\circ} \mathrm{C} \\
t=20 \mathrm{~h} \\
\mathrm{CH}_{4} / \mathrm{CO}_{2} \\
4: 1-1: 2^{\mathrm{a}} \\
\mathrm{SV}=6- \\
18 \mathrm{~L} / \mathrm{h} \cdot \mathrm{g}\end{array}$ & $\begin{array}{l}27- \\
95\end{array}$ & $\begin{array}{l}30- \\
97\end{array}$ & - & - & [110] \\
\hline $\mathrm{Ni} / \mathrm{MgO}$ & $\begin{array}{l}\text { surfactant- } \\
\text { assisted } \\
\text { precipitation }\end{array}$ & $\begin{array}{l}\mathrm{Ni}: \\
5-15 \text { wt \%, } \\
\text { Mg/Al 1:1a } \\
\text { optimum } \\
7 \text { wt } \% \mathrm{Ni}\end{array}$ & $\begin{array}{l}T=500{ }^{\circ} \mathrm{C} \\
t=2 \mathrm{~h}\end{array}$ & $\begin{array}{l}P=1 \mathrm{~atm} \\
T=550- \\
700{ }^{\circ} \mathrm{C} \\
t=5 \mathrm{~h} \\
\mathrm{CH}_{4} / \mathrm{CO}_{2} \\
2: 1-1: 3^{\mathrm{a}} \\
\mathrm{SV}=6- \\
24 \mathrm{~L} / \mathrm{h} \cdot \mathrm{g}\end{array}$ & $\begin{array}{l}67.5- \\
97.2\end{array}$ & $\begin{array}{l}62.4- \\
97.4\end{array}$ & $\begin{array}{l}0.58- \\
0.97\end{array}$ & - & [111] \\
\hline NiMgAl & sol-gel & $\begin{array}{l}\mathrm{Ni}: 5 \text { wt } \%, \\
\mathrm{Mg} / \mathrm{Al} \\
5: 1-1: 5^{\mathrm{a}}\end{array}$ & $\begin{array}{l}T=600{ }^{\circ} \mathrm{C}, \\
t=4 \mathrm{~h}\end{array}$ & $\begin{array}{l}P=1 \mathrm{~atm}, \\
T=550- \\
700{ }^{\circ} \mathrm{C} \\
t=5 \mathrm{~h}, \\
\mathrm{CH}_{4} / \mathrm{CO}_{2} 1: 1^{\mathrm{a}}, \\
\mathrm{SV}=12 \mathrm{~L} / \mathrm{h} \cdot \mathrm{g}\end{array}$ & 55 & 80 & 1.2 & - & [112] \\
\hline $\begin{array}{l}\mathrm{Ni}_{0.5} \mathrm{Mg}_{2.5} \mathrm{Al}_{0.9} \\
\mathrm{La}_{0.1} \mathrm{O}_{4.5}\end{array}$ & $\begin{array}{l}\text { co- } \\
\text { precipitation }\end{array}$ & $\begin{array}{l}\text { La: } \\
0.04-0.15^{a}\end{array}$ & $\begin{array}{l}T=500{ }^{\circ} \mathrm{C} \\
t=16 \mathrm{~h}\end{array}$ & $\begin{array}{l}P=1 \mathrm{~atm}, \\
T=600- \\
700{ }^{\circ} \mathrm{C}, \\
t=13 \mathrm{~h}, \\
\mathrm{CH}_{4} / \mathrm{CO}_{2} 1: 1^{\mathrm{a}}, \\
\mathrm{SV}=7200 \mathrm{~h}^{-1}\end{array}$ & 96 & 90 & 1.1 & 20.8 wt \% & [113] \\
\hline
\end{tabular}

amolar ratio; ${ }^{b}$ weight ratio.

The recorded performance might be influenced by the high surface area of $\mathrm{Al}_{2} \mathrm{O}_{3}$ and the high alkaline properties and thermal stability of $\mathrm{MgO}$, which is more suitable for $\mathrm{CO}_{2}$ and $\mathrm{CH}_{4}$ adsorption. In fact, $\mathrm{MgO}$ offers low surface area, which could further be improved, and yields optimum texture properties with a combination of alumina [45,114-117].
Based on the investigation of the morphology, structure, and catalytic properties of the $\mathrm{Ni}-\mathrm{Ce} / \mathrm{Mg}-\mathrm{Al}$ catalyst in DRM by Daza et al. [50], Ce and $\mathrm{Mg}$ are concluded to exert a synergistic effect on $\mathrm{CO}_{2}$ adsorption. Although the basic properties of $\mathrm{Ce}$ exert a significant effect on catalyst basicity, the bulk $\mathrm{CeO}_{2}$ possesses low basic properties. Therefore, the combination of 
$\mathrm{Ce}$ with $\mathrm{Mg}$ improves the catalyst basicity site. $\mathrm{CeO}_{2}$, commonly known for its oxygen storage capacity, contains a great concentration of highly mobile oxygen vacancies which could reduce the deposition of carbon on the catalyst surface [76]. In fact, $\mathrm{CO}_{2}$ molecules are more attracted to the base center (- $\mathrm{Mg}-\mathrm{OH}$ group) and then dissociate on $\mathrm{Ce}_{2} \mathrm{O}_{3}$ via electron transfer to $\mathrm{CO}_{2}$ through oxygen vacancies to form $\mathrm{CO}_{2}$ and $\mathrm{CeO}_{2}$. Thus, the base center is most suitable for adsorbing the largest amount of $\mathrm{CO}_{2}$. The catalyst was stable for up to $50 \mathrm{~h}$ of reaction at $700{ }^{\circ} \mathrm{C}$ with an equal feed $\mathrm{CO}_{2} / \mathrm{CH}_{4}$ ratio. The conversion of $\mathrm{CO}_{2}$ and $\mathrm{CH}_{4}$ was in the range of 70 to $80 \%$ when the obtained $\mathrm{H}_{2} / \mathrm{CO}$ ratio was between 1 and 1.5.

The influence of the synthesis method on the $\mathrm{Ni} / \mathrm{Al}_{2} \mathrm{O}_{3}-\mathrm{MgO}$ catalyst by sol-gel and impregnation techniques was investigated by Hassani Rad et al. [37]. A higher specific surface area $\left(178 \mathrm{~m}^{2} / \mathrm{g}\right)$ was recorded with the $\mathrm{MgO}$-doped catalyst obtained by the sol-gel method than that obtained using the impregnation method $\left(70 \mathrm{~m}^{2} / \mathrm{g}\right)$. As a consequence, the preparation technique significantly affected the catalytic performance of the $\mathrm{Ni} / \mathrm{Al}_{2} \mathrm{O}_{3}-\mathrm{MgO}$ catalyst and the $\mathrm{Ni} / \mathrm{Al}_{2} \mathrm{O}_{3}-\mathrm{MgO}$ catalyst prepared using the sol-gel method, exhibiting large yields for $\mathrm{H}_{2}, \mathrm{CO}$, and $\mathrm{H}_{2} / \mathrm{CO}$, which were $90 \%, 98 \%$, and $98 \%$, respectively, at a reaction temperature of $850{ }^{\circ} \mathrm{C}$. Evidently, the application of the sol-gel method and $\mathrm{MgO}$ as a support promoter improved the surface area and $\mathrm{Ni}$ dispersion and resulted in highly homogeneous morphology and small particle size but affected the adsorption of reactants on the catalyst. This research study is associated with the work of Sajjadi et al. [38], who used the sol-gel method to prepare a $\mathrm{Ni}-\mathrm{Co} /$ $\mathrm{Al}_{2} \mathrm{O}_{3}-\mathrm{MgO}-\mathrm{ZrO}_{2}$ catalyst. The findings showed that application of the sol-gel method with the addition of $\mathrm{MgO}$ as a support promoter produced considerable homogeneity of metal composition, small particle size, and enhanced the particle distribution and surface area.

In the study conducted by Min et al. [104], a comparative study was conducted between the sol-gel and co-precipitation methods for the preparation of a $\mathrm{Ni}-\mathrm{MgO}-\mathrm{Al}_{2} \mathrm{O}_{3}$ catalyst. The $\mathrm{Ni}$ particle size was uniformly distributed in the catalysts prepared via sol-gel. TGA results clearly showed that $13 \%$ and $7.7 \%$ carbon was deposited on the catalysts prepared via the sol-gel method and the co-precipitation method, respectively. Therefore, they concluded that the sol-gel method is preferable for $\mathrm{Ni}-\mathrm{MgO}-\mathrm{Al}_{2} \mathrm{O}_{3}$ catalyst preparation and possibly for inhibiting the formation of carbon. Xu et al. [106] prepared a $\mathrm{Ni} / \mathrm{MgO} / \gamma-\mathrm{Al}_{2} \mathrm{O}_{3}$ catalyst via the cold plasma technique and discovered an enhanced distribution of Ni particles. Moreover, the addition of $\mathrm{MgO}$ in this catalyst prevented the agglomeration of Ni particles and increased the basicity of the catalyst; consequently, more $\mathrm{CO}_{2}$ was adsorbed on the catalyst surface.
The adsorption and activation of $\mathrm{CO}_{2}$ decreased the carbon deposition. Notably, the catalyst performance showed high stability for up to $400 \mathrm{~h}$ of reaction. Fan et al. [52] carried out DRM over a $\mathrm{Ni}-\mathrm{Co} / \mathrm{MgO}-\mathrm{ZrO}_{2}$ catalyst synthesized by applying impregnation and surfactant-assisted impregnation methods. Reportedly, $\mathrm{MgO}$ stabilized $t-\mathrm{ZrO}_{2}$ and influenced the particle size. Furthermore, the addition of $\mathrm{MgO}$ to the $\mathrm{ZrO}_{2}$ support suppressed carbon deposition, which occurred between the crystallites of $t-\mathrm{ZrO}_{2}$ and prohibited a shift of the zirconia support from the tetragonal phase to the monoclinic phase. This catalyst tends to survive with low carbon formation $\left(0.89 \mathrm{mg} / \mathrm{g}_{\text {catalyst }} / \mathrm{h}\right.$ for $40 \mathrm{~h}$ with $\mathrm{CO}_{2}$ and $\mathrm{CH}_{4}$ conversion of $80 \%$ and $84 \%$, respectively). García et al. [103] studied the effects of $\mathrm{MgO}$ on the basicity and performance of the $\mathrm{Ni} / \mathrm{ZrO}_{2}$ catalyst in DRM. The catalyst was synthesized using two methods, wet impregnation and co-precipitation. A high carbonaceous residue $(0.8 \mathrm{mg} \mathrm{C} / \mathrm{mg}$ catalyst) was discovered on the catalyst surface with the absence of $\mathrm{Mg}$ in comparison to the amount of carbon deposition of $0.26 \mathrm{mg} \mathrm{C} / \mathrm{mg}$ catalyst on the catalyst with an additional of $2.3 \%$ and $0.4 \% \mathrm{MgO}$. The conversion for $\mathrm{CO}_{2}$ and $\mathrm{CH}_{4}$ was $30 \%$ and $32 \%$, respectively. The presence of $\mathrm{MgO}$ in the catalyst resulted in increased thermal stability in stabilizing the zirconia tetragonal phase, improved basicity sites for the support, and decreased reducibility of $\mathrm{Ni}^{2+}$.

Li et al. [118] designed a Ni@Ni-Mg phyllosilicate core-shell

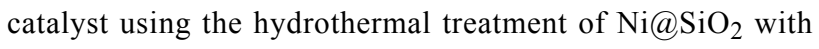
$\mathrm{Mg}\left(\mathrm{NO}_{3}\right)_{2}$. The alkalinity and porosity of the catalyst can be controlled during various hydrothermal treatment durations applied (such as 2.5, 10, and $24 \mathrm{~h}$ ). Interestingly, the optimum hydrothermal treatment time for this catalyst was $10 \mathrm{~h}$, resulting in good catalytic performance of $80 \%$ and $78 \% \mathrm{CO}_{2}$ and $\mathrm{CH}_{4}$ conversion, respectively. Moreover, the increase in hydrothermal treatment time enhanced the basicity of the catalyst from the high exposure to the $\mathrm{Mg}$ phase. The strong basicity properties of $\mathrm{Mg}$ enhanced $\mathrm{CO}_{2}$ adsorption and suppressed carbon deposition via the reverse Boudouard reaction $\left(\mathrm{C}+\mathrm{CO}_{2} \leftrightarrow\right.$ $2 \mathrm{CO}$ ). However, the core-shell structure became unstable when the catalyst was exposed to an excessively long treatment time.

Wang et al. [119] prepared and analyzed a MgO-SBA-15 catalyst via two different methods, which are the one-pot synthesis method and impregnation method as shown in Figure 9a. As a result, the catalyst prepared using the one-pot synthesis showed a better order of $\mathrm{MgO}$-coated sample in the mesostructure of SBA-15, a larger BET surface area, and formed more basic sites compared to the conventional impregnation method. The authors further impregnated the basic sites with nickel metal and tested it in DRM. The MgO-coated Ni/SBA-15 catalysts showed greater catalyst performance and stability compared to the Ni/SBA-15 sample. Figure $9 \mathrm{~b}$ depicts the total petroleum 
(a)
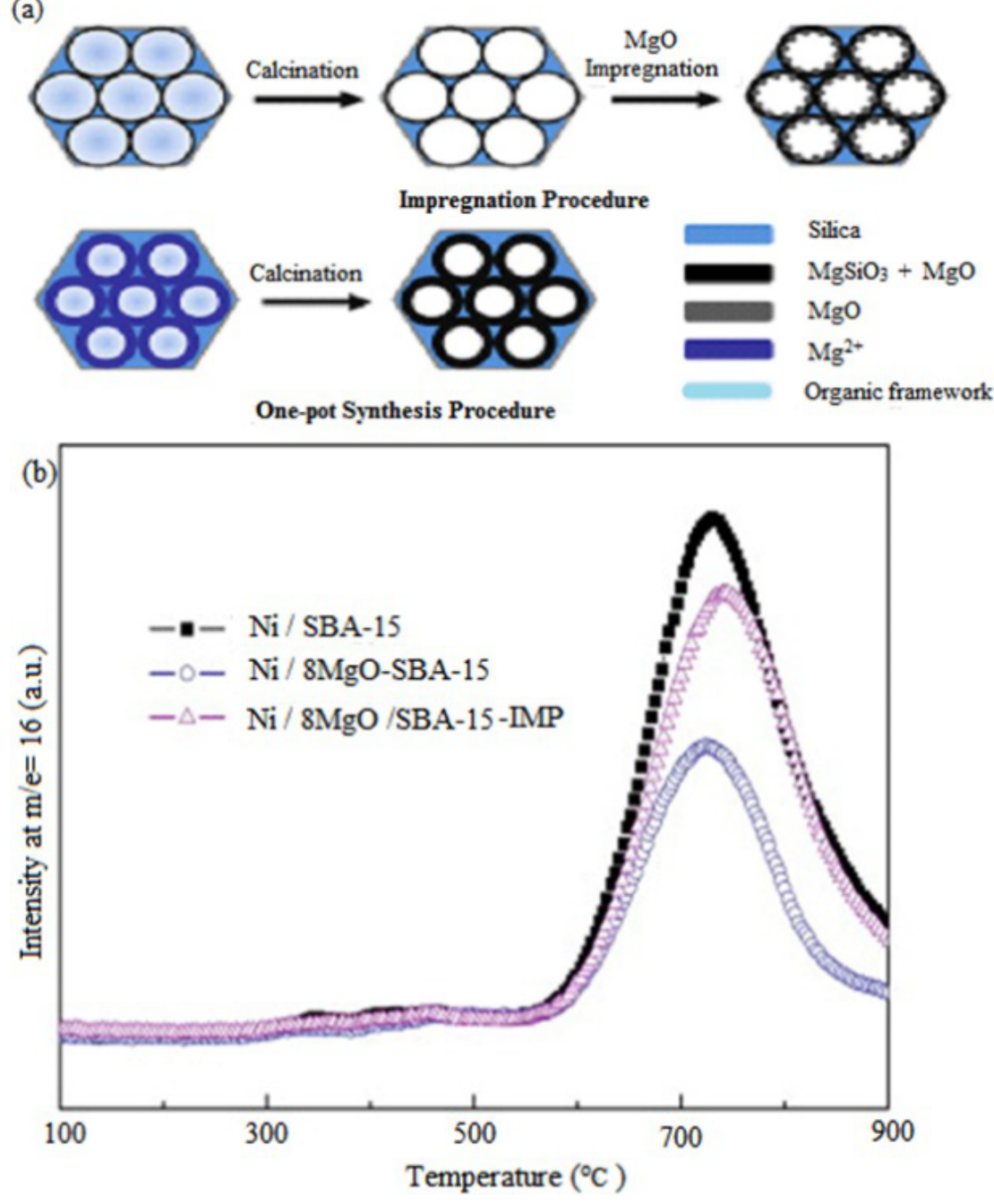

Figure 9: (a) Schematic illustration of the two synthesis methods for the MgO basic sites formation on SBA-15, (b) TPH profiles of spent catalysts after $40 \mathrm{~h}$ stability test. Reprinted with permission from [119], copyright 2013 Elsevier.

hydrocarbons (TPH) profiles of spent catalyst after $40 \mathrm{~h}$ of stability. It is interesting to note that $8 \mathrm{wt} \%$ of $\mathrm{MgO}$ loading exhibited excellent catalytic activity. The SBA-15 supported catalyst showed that the confinement of pore walls inhibited the $\mathrm{Ni}$ particle aggregation. Meanwhile, the $\mathrm{MgO}$ coating showed a higher dispersion of $\mathrm{Ni}$ metal and highly basic sites than the $\mathrm{MgO}$ impregnated method. It was also found that this structure improved stability and could inhibit the formation of filamentous and encapsulating carbon. Deactivation of the catalyst occurs over the Ni/SBA-15 sample since a large amount of graphitic carbon species were formed.

\section{Application of $\mathrm{Mg}$ as a promoter of active metal}

Elsayed et al. [51] demonstrated DRM over $\mathrm{Pt}-\mathrm{Ni}-\mathrm{Mg}$ / ceria-zirconia synthesized via precipitation and the incipient wetness method. The largest amount of basic sites were found in the $\mathrm{Ni}-\mathrm{Mg} /\left(\mathrm{Ce}_{0.6} \mathrm{Zr}_{0.4}\right) \mathrm{O}_{2}$ catalyst, but the basicity site characteristics decreased with the addition of $\mathrm{Pt}$ to the catalyst. Consequently, the lowest $\mathrm{CO}_{2}$ and $\mathrm{CH}_{4}$ conversions were obtained and no carbon was deposited on the catalyst surface. Moreover, the catalyst was of a good composition, given that the DRM process could be performed within the low temperature range of $430{ }^{\circ} \mathrm{C}$ to $470{ }^{\circ} \mathrm{C}$. The catalyst was stable for up to $100.5 \mathrm{~h}$ without carbon deposition.

García-Diéguez et al. [19] developed a Ni-Mg active metal material supported on alumina via the reverse microemulsion method and impregnation method in a comparative study. $\mathrm{Mg}$ was proven to stabilize $\mathrm{Ni}$ on the catalyst surface by preventing the diffusion of Ni particles into the alumina lattice, indirectly suppressing carbon deposition. Table 4 shows the average particle size of $\mathrm{Ni}$ and carbon content in the catalysts after the reac- 


\begin{tabular}{|c|c|c|c|c|}
\hline \multirow[t]{2}{*}{ Catalyst } & \multicolumn{2}{|l|}{ DRM } & \multicolumn{2}{|l|}{ DRP } \\
\hline & $D_{\mathrm{p}} \mathrm{Ni}^{0}(\mathrm{~nm})^{\mathrm{a}}$ & C content $(w t \%)^{b}$ & $D_{\mathrm{p}} \mathrm{Ni}^{0}(\mathrm{~nm})^{\mathrm{a}}$ & C content $(w t \%)^{b}$ \\
\hline $\mathrm{NiMg} / \mathrm{Al}_{2} \mathrm{O}_{3} \mathrm{IM}$ & 20 & 13 & 25 & 26 \\
\hline $\mathrm{NiMg} / \mathrm{Al}_{2} \mathrm{O}_{3} \mathrm{ME}$ & 16 & 0.5 & 16 & 5 \\
\hline
\end{tabular}

${ }^{a}$ Calculated by the Scherrer equation; ${ }^{b}$ Obtained by elemental analysis.

tion. The $\mathrm{NiMg} / \mathrm{Al}_{2} \mathrm{O}_{3}$ catalyst synthesized using the microemulsion method recorded a lower particle size $(16 \mathrm{~nm})$ and carbon content $(0.5 \mathrm{wt} \%)$ compared with that of the $\mathrm{NiMg} /$ $\mathrm{Al}_{2} \mathrm{O}_{3}$ catalyst prepared via the impregnation method $(20 \mathrm{~nm}$ for and $13 \mathrm{wt} \%$, respectively). Based on the reactivity in DRM, both $\mathrm{NiMg} / \mathrm{Al}_{2} \mathrm{O}_{3}$ catalysts prepared via different methods showed similar $\mathrm{CO}_{2}$ conversion of $27 \%$ at a reaction temperature of $600{ }^{\circ} \mathrm{C}$, whereas the $\mathrm{NiMg} / \mathrm{Al}_{2} \mathrm{O}_{3}$ catalyst prepared via the impregnation method showed a slightly higher $\mathrm{CO}_{2}$ conversion of $71 \%$ at a reaction temperature of $700{ }^{\circ} \mathrm{C}$. The $\mathrm{NiMg} /$ $\mathrm{Al}_{2} \mathrm{O}_{3}$ catalyst synthesized via reverse microemulsion showed a $\mathrm{CH}_{4}$ conversion of $58 \%$, which was higher than that of the catalyst prepared via other methods. The obtained ratios of $\mathrm{H}_{2} / \mathrm{CO}$ for the catalysts prepared using both methods were not markedly different, at $0.66-0.67$. In terms of the preparation method, the reverse microemulsion method was preferable for the DRM process, owing to the good activity and stability of the catalyst, which minimized carbon deposition and caused considerable interaction between $\mathrm{Ni}$ and $\mathrm{Mg}$.

Macedo Neto et al. [120] studied the synthesis of Ce in $\mathrm{Ni}-\mathrm{Mg}-\mathrm{Al}$ layered double hydroxides by co-precipitation using ultrasonication. Sonication significantly increased not only the specific surface area but also the incorporation of $\mathrm{Ce}$ in the structure. In fact, the ultrasonication method guarantees a uniform distribution of nanoparticles on the catalyst support without aggregation. Zhu et al. [105] introduced $\mathrm{Mg}$ as a promoter to the $\mathrm{Ni} / \mathrm{SiO}_{2}$ catalyst synthesized via the impregnation method. The $\mathrm{Ni}-\mathrm{Mg} / \mathrm{SiO}_{2}$ catalyst was deactivated after a $30 \mathrm{~h}$ of reaction time due to the deposition of inert carbon, which is difficult to oxidize. However, the addition of $\mathrm{Mg}$ caused the reduction of the RWGS reaction; thus, a high $\mathrm{H}_{2}$ production was obtained.

Yan et al. [121] investigated the effects of the addition of $\mathrm{MgO}$ on the Ni catalyst in the DRM. In their investigation, a good dispersion of nickel oxide and $\mathrm{MgO}$ promoter was reported over a $\gamma-\mathrm{Al}_{2} \mathrm{O}_{3}$ support. In addition, the $\mathrm{MgO}$ promoter remarkably retarded the formation of the $\mathrm{NiAl}_{2} \mathrm{O}_{4}$ phase during the reaction. The addition of $\mathrm{MgO}$ to the catalyst in the presence of
$\mathrm{CeO}_{2}$ inhibited self-dispersion and promoted $\mathrm{Ni}$ dispersion on the catalysts. Alipour et al. [68] reported that the addition of $\mathrm{MgO}$ to the Ni catalysts supported on nanocrystalline $\mathrm{Al}_{2} \mathrm{O}_{3}$ decreased the surface area of the catalysts. $\mathrm{MgO}$ has the most beneficial effect for catalytic activity and suppressed the carbon formation in comparison with other alkaline earth promoters such as $\mathrm{CaO}$ and $\mathrm{BaO}$ investigated in this work. In fact, adding $\mathrm{MgO}$ to the catalyst decreased the reduction temperature of the $\mathrm{NiO}$ species and increased the catalyst reducibility.

\section{Influence of metal loading}

Khajenoori et al. [110] conducted the DRM reaction over a $\mathrm{Ni}-\mathrm{CeO}_{2} / \mathrm{MgO}$ catalyst with various $\mathrm{Ni}$ loadings (5-15 wt \%) at a temperature of $550{ }^{\circ} \mathrm{C}$ to $700{ }^{\circ} \mathrm{C}$. Thus, the $\mathrm{CO}_{2}$ and $\mathrm{CH}_{4}$ conversions showed significant increments when the Ni loading increased up to $10 \mathrm{wt} \%$. However, the catalyst performance decreased with Ni loading greater than wt $\%$ because of the formation of large Ni crystals and, consequently, low dispersion. Moreover, the $10 \% \mathrm{Ni}-7 \% \mathrm{CeO}_{2} / \mathrm{MgO}$ catalyst was highly stable for $20 \mathrm{~h}$ of reaction without a decrease in $\mathrm{CH}_{4}$ conversion for the $\mathrm{CO}_{2}$ reforming reaction.

Meshkani et al. [111] studied the effect of Ni loading on the catalytic activity of a $\mathrm{Ni} / \mathrm{MgO}$ catalyst in the $\mathrm{DRM}$ reaction. The $\mathrm{CO}_{2}$ and $\mathrm{CH}_{4}$ conversion, $\mathrm{H}_{2} / \mathrm{CO}$ ratio, and $\mathrm{H}_{2}$ and $\mathrm{CO}$ yields showed a progressive increase as the Ni loading increased from $5 \mathrm{wt} \%$ to $7 \mathrm{wt} \%$. In contrast, the conversion yields decreased with higher Ni loading of 10 and $15 \mathrm{wt} \%$. The conversion yields decreased because of low Ni dispersion. Meanwhile, the $\mathrm{H}_{2} / \mathrm{CO}$ ratio was reduced due to the occurrence of RWGS. In terms of stability, carbon deposition was observed at the $\mathrm{Ni}$ / $\mathrm{MgO}$ catalyst with $15 \mathrm{wt} \% \mathrm{Ni}$ loading. However, this deposition could not deactivate the catalyst, and high stability was recorded up to a reaction time of $300 \mathrm{~min}$. Furthermore, the reduced $\mathrm{NiO}-\mathrm{MgO}$ solid solution catalysts could inhibit carbon deposition owing to the strong synergistic effect between high $\mathrm{Ni}$ dispersion and basicity of the $\mathrm{MgO}$ support. In contrast, Meshkani et al. [108] reported that low Ni loading results in low conversion of $\mathrm{CO}_{2}$ and $\mathrm{CH}_{4}$ over the $\mathrm{Ni} / \mathrm{MgO}$ catalyst as shown in Figure 10. This finding is due to fewer NiO species being 
reduced to metallic species, thus minimizing the amount of active sites for the reaction. Stable conversion of $\mathrm{CO}_{2}$ and $\mathrm{CH}_{4}$ at $70 \%$ and $55 \%$, respectively, were observed for the $\mathrm{Ni} / \mathrm{MgO}$ catalyst with $5 \mathrm{wt} \%$ of $\mathrm{Ni}$ loading for long-term reactions up to $50 \mathrm{~h}$.
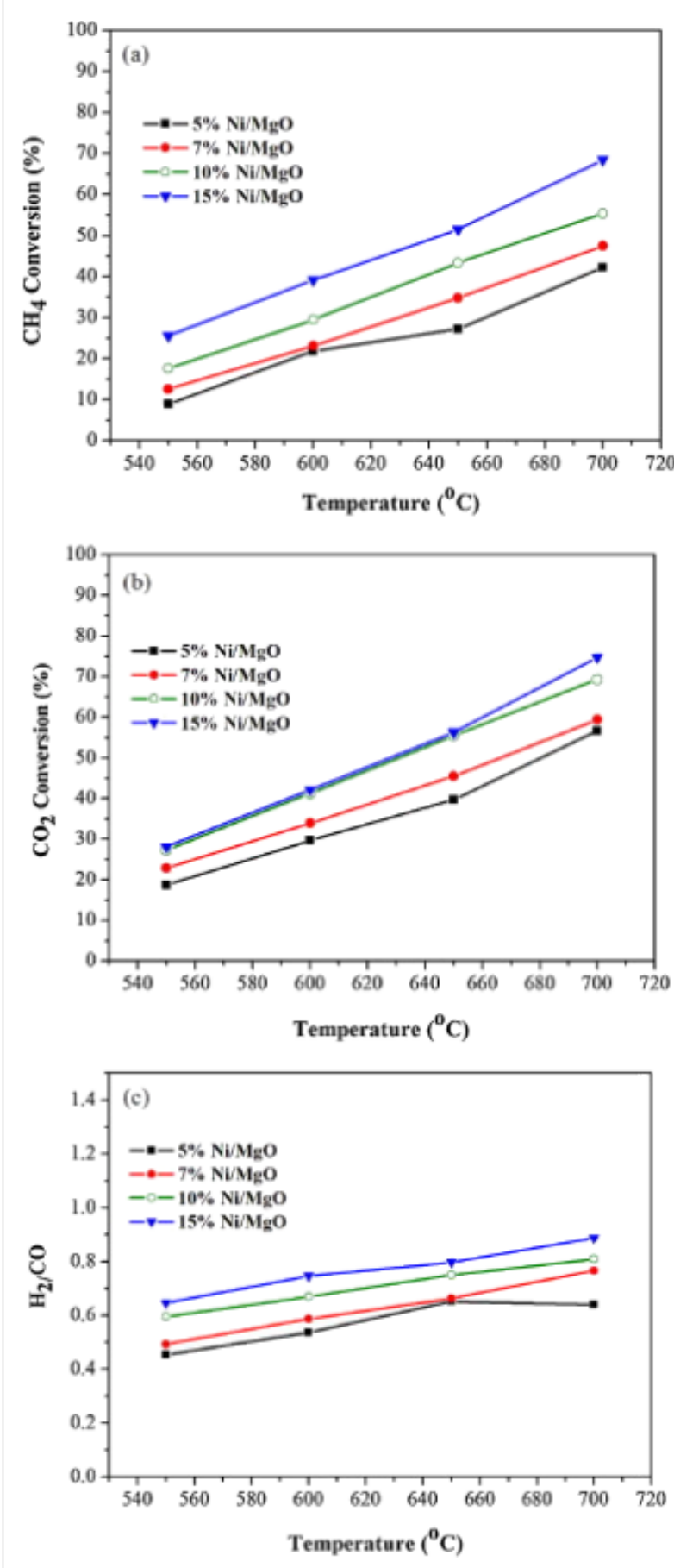

Figure 10: (a) $\mathrm{CH}_{4}$ conversion, (b) $\mathrm{CO}_{2}$ conversion, (c) $\mathrm{H}_{2} / \mathrm{CO}$ ratio of catalysts with different nickel loadings in the DRM reaction, $\mathrm{CH}_{4} / \mathrm{CO}_{2}$ $1: 1$ and gas hourly space velocity (GHSV) of $1.8 \times 10^{4} \mathrm{~mL} / \mathrm{h} \cdot \mathrm{g}_{\text {cat. }}$ Reprinted with permission from [108], copyright 2014 Elsevier.
The high stability is due to the high basicity of the support and the formation of solid solution, thus inhibiting carbon deposition. Figure 11 shows the stability of the DRM reaction on the $\mathrm{Ni} / \mathrm{MgO}$ catalysts with various nickel loadings at $700{ }^{\circ} \mathrm{C}$.

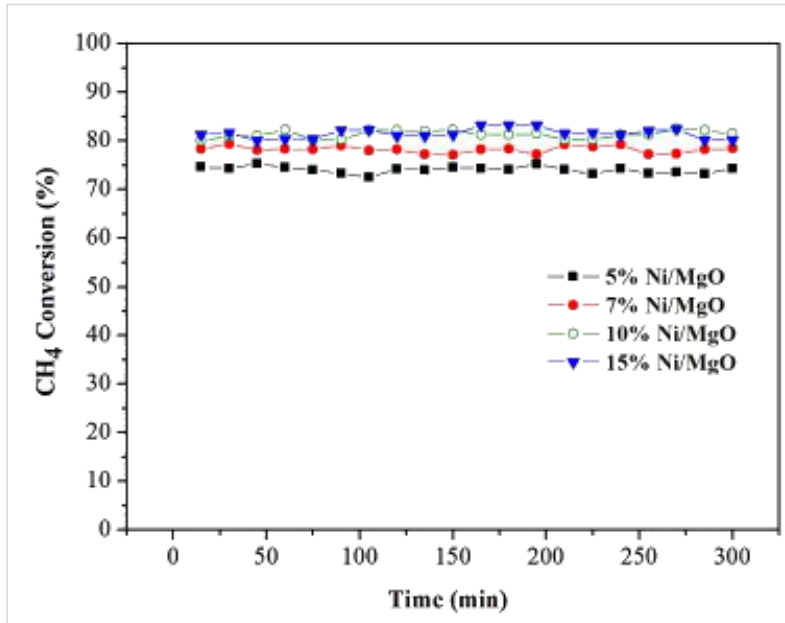

Figure 11: Stability of $\mathrm{CH}_{4}$ conversion over Ni/MgO catalysts with different Ni loadings (5\% to $15 \%$ ) in a DRM reaction at $700{ }^{\circ} \mathrm{C}, \mathrm{CH}_{4} / \mathrm{CO}_{2}$ $1: 1$, and gas hourly space velocity (GHSV) of $1.8 \times 104 \mathrm{~mL} / \mathrm{h} \cdot \mathrm{g}_{\text {cat }}$. Reprinted with permission from [108], copyright 2014 Elsevier.

Lin et al. [109] inspected the effect of Ni loading (2-20 wt \%) on the $\mathrm{Ni} / \mathrm{MgO}$ (111) catalyst prepared via the impregnation method. According to the morphology results, the $6 \mathrm{wt} \%$ $\mathrm{Ni} / \mathrm{MgO}$ (111) catalyst showed a high $\mathrm{Ni}$ dispersion of $21.3 \%$ and a small particle size of $4.7 \mathrm{~nm}$. The catalytic performance of the $\mathrm{Ni} / \mathrm{MgO}(111)$ catalyst increased as the Ni loading increased from $2 \%$ to $10 \%$; however, adverse effects were observed for the applied catalyst with $20 \% \mathrm{Ni}$ loading. This finding may be explained by the decrease in metal dispersion and formation of large particles when the highest Ni loading was employed. Moreover, the $2 \mathrm{wt} \% \mathrm{Ni} / \mathrm{MgO}(111)$ catalyst produced a small particle size catalyst and was more easily oxidized during the reaction, possibly causing catalyst sintering. Meanwhile, Ni loading exceeding 6\% may result in a larger particle size and poor oxidizability, thereby yielding high stability and consequent carbon deposition.

Sajjadi et al. [38] investigated the influence of $\mathrm{MgO}$ loading to feed conversion, product yield, $\mathrm{H}_{2} / \mathrm{CO}$ ratio, and stability over a $\mathrm{Ni}-\mathrm{Co} / \mathrm{Al}_{2} \mathrm{O}_{3}-\mathrm{MgO}-\mathrm{ZrO}_{2}$ catalyst. The findings showed that the feed conversion increased as the metal loading of $\mathrm{MgO}$ increased. Notably, a $25 \mathrm{wt} \%$ of $\mathrm{MgO}$ loading showed the highest conversion of $\mathrm{CO}_{2}$ and $\mathrm{CH}_{4}$ with all applied reaction temperatures ranging from $550{ }^{\circ} \mathrm{C}$ to $850{ }^{\circ} \mathrm{C}$ as exhibited in Figure 12. This finding indicates a small particle size distribution, good morphology, and high surface area of the catalyst, as well as high diffusion of active metal without agglomeration 
during the reaction. Moreover, the average particle size was $11.6 \mathrm{~nm}$, which was small enough to suppress carbon formation. Meanwhile, the product yield appeared to be markedly affected by the increment in $\mathrm{MgO}$ loading. The optimum yield of $\mathrm{H}_{2}$ and $\mathrm{CO}$ of 96.9 and 97.1 , respectively, were recorded over the $\mathrm{Ni}-\mathrm{Co} / \mathrm{Al}_{2} \mathrm{O}_{3}-\mathrm{MgO}-\mathrm{ZrO}_{2}$ catalyst containing $25 \mathrm{wt} \% \mathrm{MgO}$ loading at a reaction temperature of $850{ }^{\circ} \mathrm{C}$. This excellent performance is due to the properties of $\mathrm{MgO}$, which provides a highly alkaline surface for $\mathrm{CO}_{2}$ adsorption. The stable yield with a $\mathrm{H}_{2} / \mathrm{CO}$ ratio close to unity was observed with the $\mathrm{Ni}-\mathrm{Co} /$ $\mathrm{Al}_{2} \mathrm{O}_{3}-\mathrm{MgO}-\mathrm{ZrO}_{2}$ catalyst with $25 \mathrm{wt} \% \mathrm{MgO}$ loading. The catalyst was highly stable in the $24 \mathrm{~h}$ reaction time without deposition of carbon. MgO promotion enhanced the metal distribution when exposed to the highly basic surface and decreased the particle size.

Min et al. [104] studied the effect of $\mathrm{Mg} / \mathrm{Al}$ ratio on catalytic activity and stability over a $\mathrm{Ni}-\mathrm{MgO}-\mathrm{Al}_{2} \mathrm{O}_{3}$ catalyst and found that the conversion of $\mathrm{CO}_{2}$ and $\mathrm{CH}_{4}$ showed improved results when $\mathrm{MgO}$ was introduced. The best catalytic performance was detected for a catalyst with a ratio of $\mathrm{MgO} /\left(\mathrm{MgO}+\mathrm{Al}_{2} \mathrm{O}_{3}\right)$ of approximately 0.44 to 0.86 . This outcome is due to the capability of $\mathrm{MgO}$ in enhancing the interaction between metal and support. Moreover, the compound improved the alkalinity of the catalyst surface, leading to increased adsorption of $\mathrm{CO}_{2}$. They proposed that the adsorbed $\mathrm{CO}_{2}$ reacted with deposited carbon to stimulate the catalyst. In a different study by Zhu et al. [112], different $\mathrm{Mg} / \mathrm{Al}$ molar ratios of 5:1, 3:1, 1:1, 1:3, and 1:5 were applied for the preparation of a $\mathrm{NiMg}_{x} \mathrm{Al}_{y}$ catalyst. The optimum $\mathrm{Mg} / \mathrm{Al}$ molar ratio of 1:1 yielded the highest $\mathrm{CO}_{2}$ and $\mathrm{CH}_{4}$ conversions of $90 \%$ and $83 \%$, respectively. These results are due to the formation of the hydrotalcite precursor for the $\mathrm{NiMgAl}$ catalyst. Moreover, $\mathrm{MgO}$ played an important role for improved catalyst performance; thus, a high $\mathrm{Mg} / \mathrm{Al}$ molar ratio corresponded to the highest conversion in the order of $\mathrm{NiMg}_{5} \mathrm{Al}_{1}>\mathrm{NiMg}_{3} \mathrm{Al}_{1}>\mathrm{NiMg}_{1} \mathrm{Al}_{3}>\mathrm{NiMg}_{1} \mathrm{Al}_{5}$. Furthermore, low carbon formation of $3.3 \mathrm{mg} / \mathrm{g}_{\text {cat }} \cdot \mathrm{h}$ was observed with the $\mathrm{NiMg}_{5} \mathrm{Al}_{1}$ catalyst. Overall, the formation of hydrotalcite and a high ratio of $\mathrm{Mg}$ could improve the performance of Ni metal and enhance the catalytic activity and stability.

Alipour et al. [122] successfully investigated the effect of alkaline earth metals, such as $\mathrm{MgO}, \mathrm{CaO}$, and $\mathrm{BaO}$, as support modifiers for a $\mathrm{Ni} / \mathrm{Al}_{2} \mathrm{O}_{3}$ catalyst. The addition of basic support modifiers resulted in the reduction of the surface area of the $\mathrm{Ni} /$ $\mathrm{Al}_{2} \mathrm{O}_{3}$ catalyst. However, these modifiers could enhance the catalyst performance and inhibit carbon deposition. Interestingly, $\mathrm{MgO}$ showed an excellent effect on catalytic activity and carbon deposition. Furthermore, they analyzed the effect of different $\mathrm{MgO}$ loadings $(1.5 \%-6 \%)$ on the $\mathrm{Ni} / \mathrm{Al}_{2} \mathrm{O}_{3}$ catalyst. A moderate amount of $\mathrm{MgO}$, that is, $3 \mathrm{wt} \%$, was suitable for the
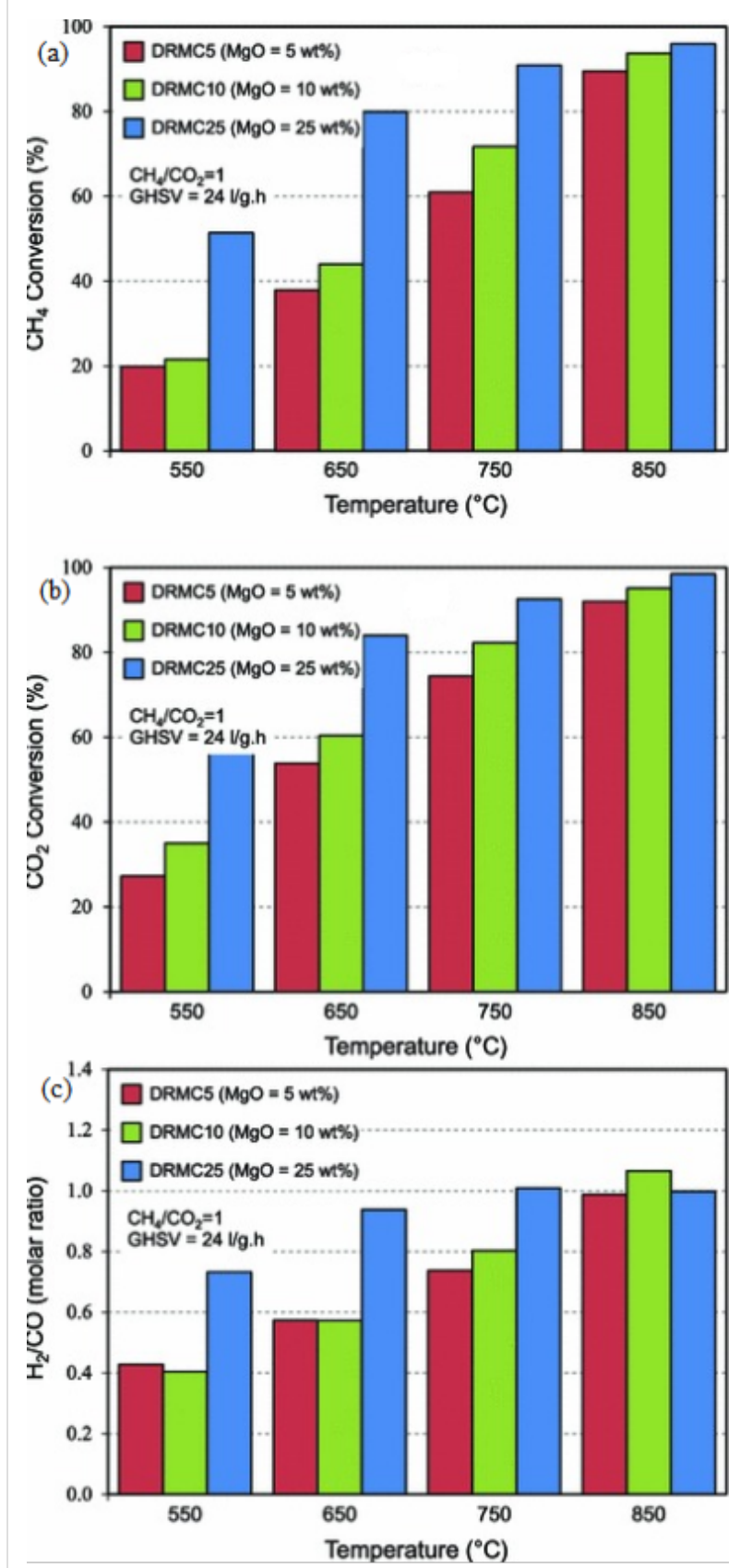

Figure 12: Effect of $\mathrm{MgO}$ loading on (a) $\mathrm{CH}_{4}$, (b) $\mathrm{CO}_{2}$ conversion and (c) $\mathrm{H}_{2} / \mathrm{CO}$ molar ratio over various $\mathrm{MgO}$ loadings (5, 10, $25 \mathrm{wt} \%$ ). Reprinted from [38], copyright 2014, Springer Nature.

$\mathrm{Ni} / \mathrm{Al}_{2} \mathrm{O}_{3}$ catalyst because of stable catalytic activity and $\mathrm{H}_{2} / \mathrm{CO}$ ratio. $\mathrm{Yu}$ et al. [113] studied the effect of $\mathrm{La}$ as a promoter to a NiMgAl catalyst and found that the addition of La enhanced the basic surface of the catalyst and improved Ni metal distribution. Moreover, the catalytic activity increased, and the stability of the $\mathrm{NiMgAl}$ catalyst considerably improved. The combination of $\mathrm{La}$ and $\mathrm{Mg}$ suppressed carbon formation. The investigation using a La molar ratio ranging from 
0.04 to 0.15 yielded the highest catalytic activity over the $\mathrm{Ni}_{0.5} \mathrm{Mg}_{2.5} \mathrm{Al}_{0.9} \mathrm{La}_{0.1} \mathrm{O}_{4.5}$ catalyst.

\section{Effect of catalyst pretreatment}

Pretreatment, such as calcination, is mainly conducted to eliminate and volatilize various catalyst precursors that are used during catalyst preparation, including hydroxides, nitrates, or carbonates, which are unnecessary for the final catalyst. High temperature treatment is typically conducted for this elimination. Notably, overheating of the solid catalyst results in high pressure because of trapped $\mathrm{H}_{2} \mathrm{O}$ molecules in the micropores, which may crack particulate carriers [95]. Feng et al. [94] investigated the influence of calcination temperature (between $600{ }^{\circ} \mathrm{C}$ to $800{ }^{\circ} \mathrm{C}$ ) on the adsorption and dissociation of $\mathrm{CO}_{2}$ by applying DRM over the $\mathrm{NiO} / \mathrm{MgO}$ catalyst. High performance and strong interactions between metal and support were observed with the calcination of the $\mathrm{NiO} / \mathrm{MgO}$ catalyst at $800{ }^{\circ} \mathrm{C}$. In addition, the catalyst calcined at $800{ }^{\circ} \mathrm{C}$ exhibited more active sites, which are strong enough to absorb $\mathrm{CO}_{2}$ on the metal surface. Moreover, $\mathrm{CO}_{2}$ was not directly adsorbed on the $\mathrm{Ni}$ metal, and dissociated $\mathrm{H}$ from $\mathrm{CH}_{4}$ cracking assisted the dissociation of $\mathrm{CO}_{2}$ into $\mathrm{CO}$. This result was in an agreement with Wang et al. [23]. Wang et al. [23] stated that the activity and stability of the $\mathrm{NiO} / \mathrm{MgO}$ catalyst was strongly dependent on calcination temperature. The calcination temperature influenced the metal/support interaction, which performs an important role in hindering sintering and carbon deposition. Moreover, the strong Lewis base property of $\mathrm{MgO}$ enabled the adsorption of more $\mathrm{CO}_{2}$ on the catalyst, consequently enhancing the conversion of reactants and minimizing the carbon deposition via a reverse Boudouard reaction (Equation 12).

In contrast, Perez-Lopez et al. [92] studied the effect of calcination temperature $\left(400{ }^{\circ} \mathrm{C}, 600{ }^{\circ} \mathrm{C}\right.$, and $\left.800{ }^{\circ} \mathrm{C}\right)$ in a DRM reaction over a $\mathrm{Ni}-\mathrm{Mg}-\mathrm{Al}$ catalyst. They stated that the increase in calcination temperature from $400{ }^{\circ} \mathrm{C}$ to $800{ }^{\circ} \mathrm{C}$ yielded a decrease in surface area values from $250 \mathrm{~m}^{2} / \mathrm{g}$ to $150 \mathrm{~m}^{2} / \mathrm{g}$, respectively. Figure 13a,b shows the conversion of $\mathrm{CO}_{2}$ and $\mathrm{CH}_{4}$ of the NiMg (loading of Ni $55 \mathrm{~mol} \%$; Mg $11 \mathrm{~mol} \%$ ) catalyst influenced by calcination temperature. As evidently seen from the results, the catalyst activity was independent of calcination temperature. However, significant differences in catalyst activity were observed, possibly as a result of the surface area of the catalyst. Moreover, this catalyst displayed high suppression of coke formation because of the synergetic effect of $\mathrm{Ni}$ and $\mathrm{Mg}$, as proven by the highest concentration of basic sites obtained from the sample with lower $\mathrm{Mg}$ compared with Ni contents. However, they proposed a $\mathrm{Ni} / \mathrm{Mg}$ ratio of lower than 5 for the best result. These results further highlighted higher carbon deposition for the catalyst calcined at $400{ }^{\circ} \mathrm{C}$ compared with those at other temperatures.
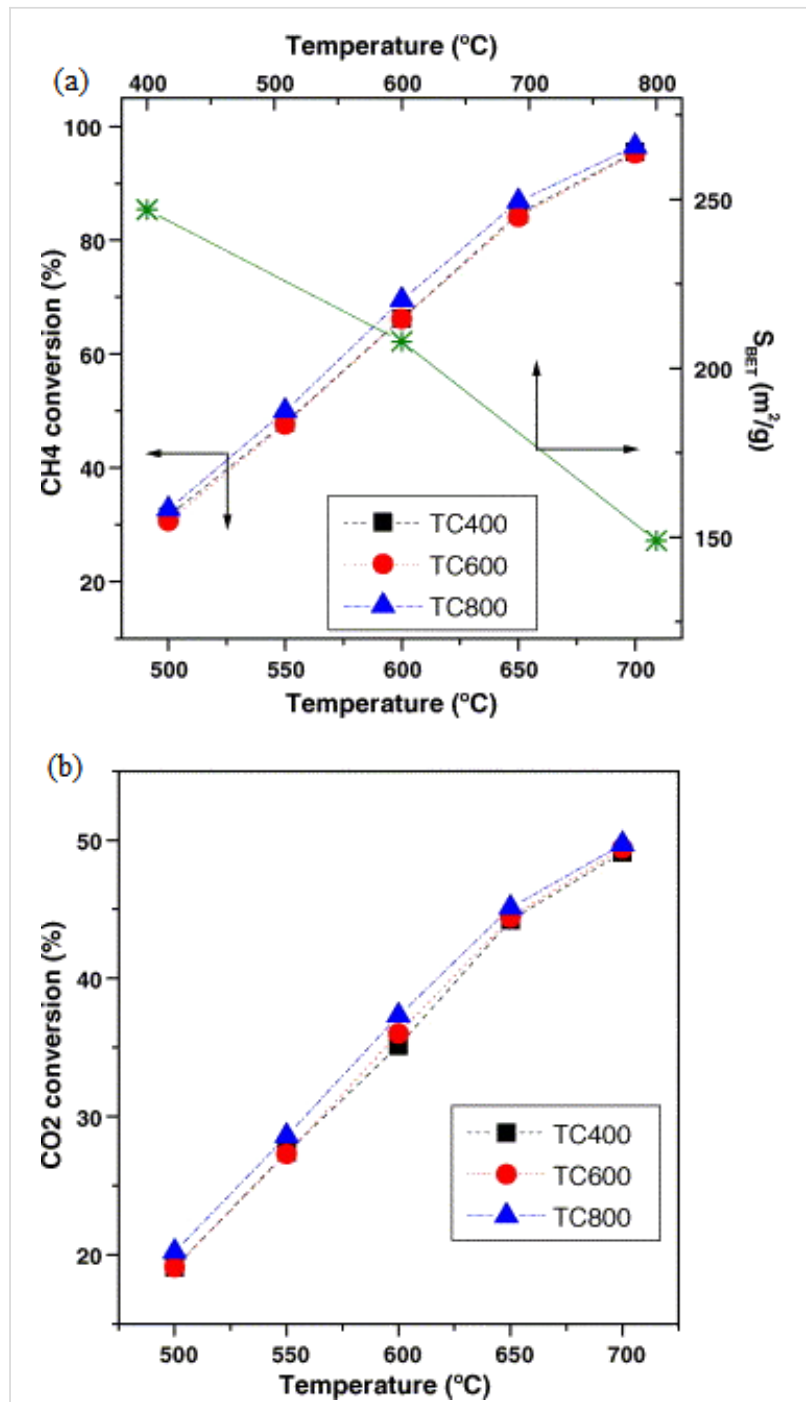

Figure 13: Conversion of methane (a) and carbon dioxide (b) on N55M11 calcined at different temperatures (-) $400{ }^{\circ} \mathrm{C},(\bullet) 600^{\circ} \mathrm{C}$ and

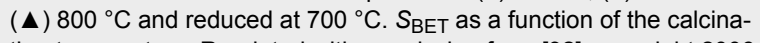
tion temperature. Reprinted with permission from [92], copyright 2006 Elsevier.

Serrano-Lotina et al. [107] investigated the influence of calcination temperature of a $\mathrm{La}-\mathrm{NiMgAl}$ catalyst for biogas reforming. The catalyst was calcined at different temperatures between $250{ }^{\circ} \mathrm{C}$ and $750{ }^{\circ} \mathrm{C}$. As a result, the grain size and cell parameter values increased with calcination temperature. The calcination temperature is extremely crucial, possibly affecting the activity and stability of the catalyst, as evidently proven by the significant decrease in activity at higher calcination temperature. An increased interaction inside the $\mathrm{Mg}(\mathrm{Ni}, \mathrm{Al}) \mathrm{O}$ solid solution leads to agglomeration, which is inefficient for the catalytic reaction. The optimized calcination temperature was $550{ }^{\circ} \mathrm{C}$ for the $\mathrm{La}-\mathrm{NiMgAl}$ catalyst to yield large catalytic activity. However, the $\mathrm{La}-\mathrm{NiMgAl}$ catalyst calcined at $750{ }^{\circ} \mathrm{C}$ was reportedly the most preferable for coke suppression. To en- 
hance catalytic performance, Son et al. [54] performed steam pretreatment over a $\mathrm{NiCoMg} / \mathrm{Al}_{2} \mathrm{O}_{3}$ catalyst. During the treatment, $\mathrm{MgAl}_{2} \mathrm{O}_{4}$ was formed on the catalyst when the unstable aluminum leached out and moved to $\mathrm{MgO}$. Aluminum leaching stimulated the acidic sites, leading to carbon deposition. Thus, the formation of $\mathrm{MgAl}_{2} \mathrm{O}_{4}$ on the catalyst enhanced the $\mathrm{CO}_{2}$ adsorption or desorption and consequently suppressed carbon deposition. From this study, long-term stability was achieved for $3000 \mathrm{~h}$ at a reaction temperature of $850{ }^{\circ} \mathrm{C}$ with high selectivity of $\mathrm{H}_{2}(93.8 \%)$ and $\mathrm{CO}(95.5 \%)$ and low carbon deposition $(1.3 \mathrm{wt} \%)$ at a rate of $0.0003\left(\mathrm{mg}_{\mathrm{c}} / \mathrm{g}_{\mathrm{cat}} \mathrm{h}\right)$.

\section{Influence of reaction conditions}

Meshkani et al. [108] carried out a DRM reaction at various temperatures from $500{ }^{\circ} \mathrm{C}$ to $700{ }^{\circ} \mathrm{C}$ for various Ni loadings on a $\mathrm{Ni} / \mathrm{MgO}$ catalyst. The catalytic activity and $\mathrm{H}_{2} / \mathrm{CO}$ ratio were significantly affected by $\mathrm{Ni}$ loading ranging between $5-15 \mathrm{wt} \%$ as the reaction temperature increased. Excellent catalyst performance was recorded for the $\mathrm{Ni} / \mathrm{MgO}$ catalyst with $15 \mathrm{wt} \% \mathrm{Ni}$ loading. Lin et al. [109] investigated the influence of the reaction temperature of $450{ }^{\circ} \mathrm{C}$ to $650{ }^{\circ} \mathrm{C}$ for various Ni loadings as displayed in Figure 14. The study found that the $\mathrm{CO}_{2}$ and $\mathrm{CH}_{4}$ conversions gradually increased with a reaction temperature of up to $650{ }^{\circ} \mathrm{C}$. The highest conversion of $\mathrm{CO}_{2}$ and $\mathrm{CH}_{4}$ of $65 \%$ and $60 \%$, respectively, was recorded at a reaction temperature of $650{ }^{\circ} \mathrm{C}$.

Meshkani et al. [111] investigated the effect of $\mathrm{CO}_{2} / \mathrm{CH}_{4}$ feed ratios of $3: 1,2: 1,1: 1$, and $1: 2$ on the catalytic activity and $\mathrm{H}_{2} /$ $\mathrm{CO}$ ratio over a $5 \mathrm{wt} \% \mathrm{Ni} / \mathrm{MgO}$ catalyst at a reaction temperature of $700{ }^{\circ} \mathrm{C}$. Table 5 shows the effect of feed ratio on the catalytic performance over a $5 \% \mathrm{Ni} / \mathrm{MgO}$ catalyst in the DRM. It could be concluded that the conversion of $\mathrm{CH}_{4}$ increased considerably as the feed ratio increased. However, the $\mathrm{CO}_{2}$ conversion and $\mathrm{H}_{2} / \mathrm{CO}$ ratio showed adverse effects.

Meshkani et al. [108] further studied the effect of $\mathrm{CO}_{2} / \mathrm{CH}_{4}$ feed ratios of $1: 2,1: 1,1.5: 1$, and $2: 1$ on a $10 \mathrm{wt} \% \mathrm{Ni} / \mathrm{MgO}$ catalyst as shown in Table 6 . The same pattern as in their previous study in [111] was observed. The highest $\mathrm{CH}_{4}$ conversion of $86.29 \%$ was obtained at a $\mathrm{CO}_{2} / \mathrm{CH}_{4}$ feed ratio of $2: 1$. Meanwhile, the highest $\mathrm{CO}_{2}$ conversion and $\mathrm{H}_{2} / \mathrm{CO}$ ratio of $81.95 \%$ and 0.91 , respectively, were obtained at $\mathrm{CO}_{2} / \mathrm{CH}_{4}$ feed ratio at 1:2. Mirzaei et al. [123] found that $\mathrm{CH}_{4}$ conversion increased as the $\mathrm{CO}_{2} / \mathrm{CH}_{4}$ feed ratio increased from 0.5 to 2 over a $10 \mathrm{wt} \% \mathrm{CoMgO}$ catalyst. However, the $\mathrm{CO}_{2}$ conversion and $\mathrm{H}_{2} / \mathrm{CO}$ ratio decreased with increasing $\mathrm{CO}_{2} / \mathrm{CH}_{4}$ feed ratio.

The catalytic performance of a Ni/MgO- $\mathrm{Al}_{2} \mathrm{O}_{3}$ catalyst was examined for the application of various gas hourly space velocity measurements between 6 and $18 \mathrm{~L} / \mathrm{h} \cdot \mathrm{g}_{\text {cat }}$ by keeping the
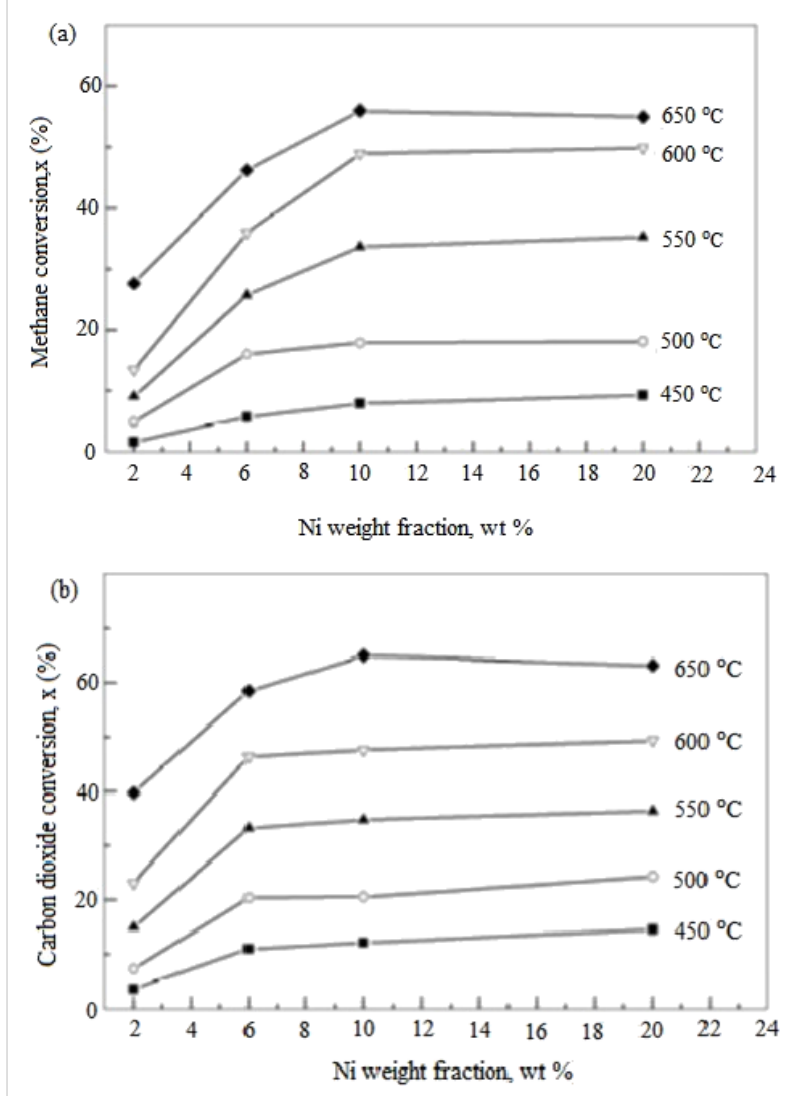

Figure 14: The effect of reaction temperature on catalyst performance (a) $\mathrm{CH}_{4}$ conversion, (b) $\mathrm{CO}_{2}$ conversion, at feed ratio $\mathrm{CH}_{4} / \mathrm{CO}_{2} 1: 1$, gas hourly space velocity (GHSV) of $36000 \mathrm{~mL} / \mathrm{h} \cdot \mathrm{g}, P=1.01 \times 10^{5} \mathrm{~Pa}$ Reprinted with permission from [109], copyright 2015 Elsevier.

Table 5: Influence of feed ratio on the catalytic performance of $5 \mathrm{wt} \%$ $\mathrm{Ni} / \mathrm{MgO}$ catalysts in DRM reaction at $700{ }^{\circ} \mathrm{C}$ and gas hourly space velocity (GHSV) of $1.0 \times 10^{4} \mathrm{~mL} / \mathrm{h} \cdot \mathrm{g}_{\text {cat }}[111]$.

\begin{tabular}{llll}
$\begin{array}{l}\text { Feed ratio } \\
\mathrm{CO}_{2} / \mathrm{CH}_{4}\end{array}$ & $\begin{array}{l}\mathrm{CH}_{4} \text { conversion } \\
(\%)\end{array}$ & $\begin{array}{l}\mathrm{CO}_{2} \text { conversion } \\
(\%)\end{array}$ & $\mathrm{H}_{2} / \mathrm{CO}$ \\
\hline $3: 1$ & 97.2 & 62.4 & 0.58 \\
$2: 1$ & 89.3 & 69.3 & 0.65 \\
$1: 1$ & 81.6 & 83.8 & 0.80 \\
$1: 2$ & 67.5 & 89.5 & 0.97
\end{tabular}

Table 6: Influence of feed ratio on the activity of a $10 \mathrm{wt} \% \mathrm{Ni} / \mathrm{MgO}$ catalyst in the DRM reaction at $700{ }^{\circ} \mathrm{C}$ and gas hourly space velocity (GHSV) of $1.8 \times 10^{4} \mathrm{~mL} / \mathrm{h} \cdot \mathrm{g}_{\text {cat }}[108]$.

\begin{tabular}{llll}
$\begin{array}{l}\text { Feed ratio } \\
\mathrm{CO}_{2} / \mathrm{CH}_{4}\end{array}$ & $\begin{array}{l}\mathrm{CH}_{4} \text { conversion } \\
(\%)\end{array}$ & $\begin{array}{l}\mathrm{CO}_{2} \text { conversion } \\
(\%)\end{array}$ & $\mathrm{H}_{2} / \mathrm{CO}$ \\
\hline $1: 2$ & 60.42 & 81.95 & 0.91 \\
$1: 1$ & 69.07 & 77.35 & 0.80 \\
$1.5: 1$ & 78.40 & 66.13 & 0.77 \\
$2: 1$ & 86.29 & 59.56 & 0.64
\end{tabular}


reaction temperature and feed ratio in the system constant ( $T=650{ }^{\circ} \mathrm{C}, \mathrm{CH}_{4} / \mathrm{CO}_{2}$ 1:1) [70]. The $\mathrm{CO}_{2}$ and $\mathrm{CH}_{4}$ conversion decreased as the space velocity increased, as exhibited in Figure 15. This is due to the insufficient contact time for the reactant on the surface of catalyst, which leads to a decrease in catalytic activity.

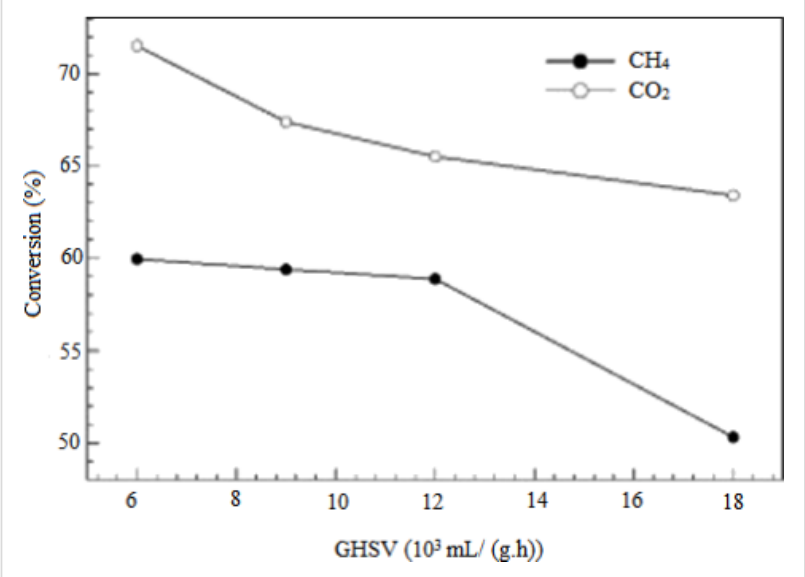

Figure 15: Influence of gas hourly space velocity (GHSV) on the catalyst performance of $20 \mathrm{wt} \% \mathrm{Ni} / 3 \mathrm{wt} \% \mathrm{MgO}-\mathrm{Al}_{2} \mathrm{O}_{3}$ catalyst at a feed ratio $\mathrm{CH}_{4} / \mathrm{CO}_{2} 1: 1, T=650^{\circ} \mathrm{C}$. Reprinted with permission from [70], copyright 2014 Elsevier.

Meshkani et al. [108] also reported the reduction of $\mathrm{CO}_{2}$ and $\mathrm{CH}_{4}$ conversion yields as the space velocity increased from $6 \mathrm{~L} / \mathrm{h} \cdot \mathrm{g}_{\text {cat }}$ to $24 \mathrm{~L} / \mathrm{h} \cdot \mathrm{g}_{\text {cat }}$ over a $10 \mathrm{wt} \% \mathrm{Ni} / \mathrm{MgO}$ catalyst. Table 7 displays the effect of gas hourly space velocity (GHSV) on the activity of a $10 \mathrm{wt} \% \mathrm{Ni} / \mathrm{MgO}$ catalyst in a DRM reaction at $700{ }^{\circ} \mathrm{C}$ and molar ratio of $\mathrm{CH}_{4} / \mathrm{CO}_{2} 1: 1$. The pattern of the $\mathrm{CH}_{4}$ conversion versus space velocity appeared similar to that of the study by Mirzaei et al. [123] over Co-MgO. Khajenoori et al. [110] investigated the space velocity of $6-18 \mathrm{~L} / \mathrm{h} \cdot \mathrm{g}_{\text {cat }}$ on $10 \mathrm{wt} \% \mathrm{Ni}-7 \mathrm{wt} \% \mathrm{CeO}_{2} / \mathrm{MgO}$ catalyst at a reaction temperature of $700{ }^{\circ} \mathrm{C}$ and a feed ratio of $\mathrm{CH}_{4} / \mathrm{CO}_{2}$ 2:1. Conversions of $\mathrm{CO}_{2}$ and $\mathrm{CH}_{4}$ showed a negative effect

Table 7: Effect of gas hourly space velocity (GHSV) on the activity of a $10 \mathrm{wt} \% \mathrm{Ni} / \mathrm{MgO}$ catalyst in DRM reaction at $700{ }^{\circ} \mathrm{C}$ and molar ratio of $\mathrm{CH}_{4} / \mathrm{CO}_{2}$ 1:1 [108].

\begin{tabular}{lll}
$\begin{array}{l}\mathrm{GHSV} 10^{4} \\
\left(\mathrm{~mL} / \mathrm{h} \cdot \mathrm{g}_{\text {cat }}\right)\end{array}$ & $\begin{array}{l}\mathrm{CH}_{4} \text { conversion } \\
(\%)\end{array}$ & $\begin{array}{l}\mathrm{CO}_{2} \text { conversion } \\
(\%)\end{array}$ \\
\hline 0.6 & 83.75 & 86.77 \\
0.9 & 80.16 & 84.33 \\
1.2 & 75.60 & 80.36 \\
1.5 & 66.14 & 70.75 \\
1.8 & 63.36 & 68.99 \\
2.4 & 58.88 & 64.61
\end{tabular}

with increasing gas hourly space velocity. This phenomenon was in agreement with the findings obtained by Meshkani et al. [108].

\section{Conclusion}

This review reported on the mechanism reaction for the DRM, mechanism of carbon formation and removal, development of Mg-containing oxide catalysts, and the effect of reaction conditions on catalytic performance. This work can be used as a reference for future works on the improvement of catalytic activity, selectivity, and stability. Through the mechanism, researchers can understand the reactions occurring in DRM, carbon deposition, and catalyst regeneration. This understanding can assist researchers in designing new multifunctional catalysts for DRM.

Two main issues requiring increased attention in catalyst development include pretreatment and the preparation method of the catalyst. First, in the catalyst preparation method for $\mathrm{Mg}$ as a promoter, the sol-gel method is more preferable, whereas cold plasma is highly suitable for synthesizing $\mathrm{Mg}$ as a support catalyst. Secondly, this review focused on the calcination temperature for catalyst pretreatment. Most researchers applied a high temperature range of $500{ }^{\circ} \mathrm{C}$ to $800{ }^{\circ} \mathrm{C}$ for markedly improving catalytic activity and minimizing carbon deposition. The analysis of the effect of reaction temperature on catalytic performance suggested that high temperatures of $800^{\circ} \mathrm{C}$ and $950{ }^{\circ} \mathrm{C}$ were suitable for high $\mathrm{CO}_{2}$ and $\mathrm{CH}_{4}$ conversion reaching $99 \%$ and could inhibit carbon deposition. Given that methane decomposition and the Boudouard reaction contribute to carbon formation, a feed ratio $\left(\mathrm{CH}_{4} / \mathrm{CO}_{2}\right)$ lower than unity should be used to suppress carbon deposition on the catalyst. All previous studies agree that the lowest space velocity is preferable for a DRM reaction to enhance catalytic activity. Optimization of metal loading for Mg-containing oxide catalysts also led to improved catalyst morphology and performance.

Despite considerable achievements by Mg-containing oxide catalysts as a support or promoter, the activity of $\mathrm{Mg}$ should be clearly specified and justified. Therefore, future investigations should focus on studying Mg-containing oxide catalysts at the molecular level to justify the capability of this highly basic catalyst for inhibiting carbon deposition in the dry reforming of methane reactions. Moreover, information on the effect of reduction on the prepared catalyst is lacking; thus, further research to analyze the effect of catalyst reduction on catalytic performance would prove highly beneficial. Reduction studies should include the composition of medium and time applied to the catalyst. Besides that, regeneration of the spent catalyst during dry reforming of methane reactions has yet to be studied extensively. This information would be extremely useful for im- 
proving catalyst performance and could be beneficial for decreasing the cost of preparing new dry reforming catalysts.

\section{Acknowledgements}

The authors express great gratitude to the Fundamental Research Grant Scheme (FRGS) - Malaysia's Rising Star Award 2015 (No: 203/PJKIMIA/6071335) from the Ministry of Higher Education of Malaysia to support this research work.

\section{ORCID ${ }^{\circledR}$ iDs}

Mehrnoush Khavarian - https://orcid.org/0000-0002-4282-8258 Abdul Rahman Mohamed - https://orcid.org/0000-0002-5418-5456

\section{References}

1. Zhang, A.-J.; Zhu, A.-M.; Guo, J.; Xu, Y.; Shi, C. Chem. Eng. J. 2010, 156, 601-606. doi:10.1016/j.cej.2009.04.069

2. Zhang, K.; Kogelschatz, U.; Eliasson, B. Energy Fuels 2001, 15, 395-402. doi:10.1021/ef0001610

3. Fan, M.-S.; Abdullah, A. Z.; Bhatia, S. ChemSusChem 2011, 4, 1643-1653. doi:10.1002/cssc.201100113

4. Rahemi, N.; Haghighi, M.; Babaluo, A. A.; Allahyari, S.; Jafari, M. F. Energy Convers. Manage. 2014, 84, 50-59. doi:10.1016/j.enconman.2014.04.016

5. Anderson, D. M.; Kottke, P. A.; Fedorov, A. G. Int. J. Hydrogen Energy 2014, 39, 17985-17997. doi:10.1016/j.ijhydene.2014.03.127

6. Angeli, S. D.; Turchetti, L.; Monteleone, G.; Lemonidou, A. A. Appl. Catal., B: Environ. 2016, 181, 34-46. doi:10.1016/j.apcatb.2015.07.039

7. Oyama, S. T.; Hacarlioglu, P.; Gu, Y.; Lee, D. Int. J. Hydrogen Energy 2012, 37, 10444-10450. doi:10.1016/j.ijhydene.2011.09.149

8. de Lima, S. M.; da Silva, A. M.; da Costa, L. O. O.; Graham, U. M.; Jacobs, G.; Davis, B. H.; Mattos, L. V.; Noronha, F. B. J. Catal. 2009, 268, 268-281. doi:10.1016/j.jcat.2009.09.025

9. Dedov, A. G.; Loktev, A. S.; Komissarenko, D. A.; Parkhomenko, K. V.; Roger, A.-C.; Shlyakhtin, O. A.; Mazo, G. N.; Moiseev, I. I. Fuel Process. Technol. 2016, 148, 128-137. doi:10.1016/j.fuproc.2016.02.018

10. Pantaleo, G.; La Parola, V.; Deganello, F.; Singha, R. K.; Bal, R.; Venezia, A. M. Appl. Catal., B: Environ. 2016, 189, 233-241. doi:10.1016/j.apcatb.2016.02.064

11. Abasaeed, A. E.; Al-Fatesh, A. S.; Naeem, M. A.; Ibrahim, A. A.; Fakeeha, A. H. Int. J. Hydrogen Energy 2015, 40, 6818-6826. doi:10.1016/j.ijhydene.2015.03.152

12. Ay, H.; Üner, D. Appl. Catal., B: Environ. 2015, 179, 128-138. doi:10.1016/j.apcatb.2015.05.013

13. Chein, R. Y.; Chen, Y. C.; Yu, C. T.; Chung, J. N. J. Nat. Gas Sci. Eng. 2015, 26, 617-629. doi:10.1016/j.jngse.2015.07.001

14. Usman, M.; Wan Daud, W. M. A.; Abbas, H. F. Renewable Sustainable Energy Rev. 2015, 45, 710-744. doi:10.1016/j.rser.2015.02.026

15. Budiman, A. W.; Song, S.-H.; Chang, T.-S.; Shin, C.-H.; Choi, M.-J. Catal. Surv. Asia 2012, 16, 183-197. doi:10.1007/s10563-012-9143-2

16. García-Vargas, J. M.; Valverde, J. L.; Díez, J.; Dorado, F.; Sánchez, P. Int. J. Hydrogen Energy 2015, 40, 8677-8687. doi:10.1016/j.ijhydene.2015.05.032
17. Hadian, N.; Rezaei, M. Fuel 2013, 113, 571-579. doi:10.1016/j.fuel.2013.06.013

18. Hadian, N.; Rezaei, M.; Mosayebi, Z.; Meshkani, F. J. Nat. Gas Chem. 2012, 21, 200-206. doi:10.1016/S1003-9953(11)60355-1

19. García-Diéguez, M.; Herrera, C.; Larrubia, M. Á.; Alemany, L. J. Catal. Today 2012, 197, 50-57. doi:10.1016/j.cattod.2012.06.019

20. Roy, P. S.; Park, C. S.; Raju, A. S. K.; Kim, K. J. CO2 Util. 2015, 12, 12-20. doi:10.1016/j.jcou.2015.09.003

21. Yasyerli, S.; Filizgok, S.; Arbag, H.; Yasyerli, N.; Dogu, G. Int. J. Hydrogen Energy 2011, 36, 4863-4874. doi:10.1016/j.ijhydene.2011.01.120

22. Rezaei, M.; Meshkani, F.; Ravandi, A. B.; Nematollahi, B.; Ranjbar, A.; Hadian, N.; Mosayebi, Z. Int. J. Hydrogen Energy 2011, 36, 11712-11717. doi:10.1016/j.ijhydene.2011.06.056

23. Wang, Y.-H.; Liu, H.-M.; Xu, B.-Q. J. Mol. Catal. A: Chem. 2009, 299, 44-52. doi:10.1016/j.molcata.2008.09.025

24. Zhao, X.; Li, H.; Zhang, J.; Shi, L.; Zhang, D. Int. J. Hydrogen Energy 2016, 41, 2447-2456. doi:10.1016/j.jhydene.2015.10.111

25. de Llobet, S.; Pinilla, J. L.; Moliner, R.; Suelves, I. Fuel 2015, 139, 71-78. doi:10.1016/j.fuel.2014.08.031

26. Tsoukalou, A.; Imtiaz, Q.; Kim, S. M.; Abdala, P. M.; Yoon, S.; Müller, C. R. J. Catal. 2016, 343, 208-214. doi:10.1016/j.jcat.2016.03.018

27. Theofanidis, S. A.; Galvita, V. V.; Poelman, H.; Marin, G. B. ACS Catal. 2015, 5, 3028-3039. doi:10.1021/acscatal.5b00357

28. Theofanidis, S. A.; Batchu, R.; Galvita, V. V.; Poelman, H.; Marin, G. B. Appl. Catal., B: Environ. 2016, 185, 42-55. doi:10.1016/j.apcatb.2015.12.006

29. San-José-Alonso, D.; Juan-Juan, J.; Illán-Gómez, M.; Román-Martínez, M. Appl. Catal., A 2009, 371, 54-59. doi:10.1016/j.apcata.2009.09.026

30. Luisetto, I.; Tuti, S.; Di Bartolomeo, E. Int. J. Hydrogen Energy 2012, 37, 15992-15999. doi:10.1016/j.ijhydene.2012.08.006

31. Gallego, G. S.; Batiot-Dupeyrat, C.; Barrault, J.; Florez, E.; Mondragón, F. Appl. Catal., A 2008, 334, 251-258. doi:10.1016/j.apcata.2007.10.010

32. Daza, C. E.; Gallego, J.; Mondragón, F.; Moreno, S.; Molina, R. Fuel 2010, 89, 592-603. doi:10.1016/j.fuel.2009.10.010

33. Xiancai, L.; Min, W.; Zhihua, L.; Fei, H. Appl. Catal., A 2005, 290, 81-86. doi:10.1016/j.apcata.2005.05.021

34. Zanganeh, R.; Rezaei, M.; Zamaniyan, A. Int. J. Hydrogen Energy 2013, 38, 3012-3018. doi:10.1016/j.ijhydene.2012.12.089

35. Cai, W.-J.; Qian, L.-P.; Yue, B.; Chen, X.-Y.; He, H.-Y. Chin. Chem. Lett. 2013, 24, 777-779. doi:10.1016/j.cclet.2013.05.034

36. Hua, W.; Jin, L.; He, X.; Liu, J.; Hu, H. Catal. Commun. 2010, 11, 968-972. doi:10.1016/j.catcom.2010.04.007

37. Hassani Rad, S. J.; Haghighi, M.; Alizadeh Eslami, A.; Rahmani, F.; Rahemi, N. Int. J. Hydrogen Energy 2016, 41, 5335-5350. doi:10.1016/j.ijhydene.2016.02.002

38. Sajjadi, S. M.; Haghighi, M.; Rahmani, F. J. Sol-Gel Sci. Technol. 2014, 70, 111-124. doi:10.1007/s10971-014-3280-1

39. Dębek, R.; Motak, M.; Duraczyska, D.; Launay, F.; Galvez, M. E.; Grzybek, T.; Da Costa, P. Catal. Sci. Technol. 2016, 6, 6705-6715. doi:10.1039/C6CY00906A

40. Singha, R. K.; Yadav, A.; Shukla, A.; Iqbal, Z.; Pendem, C.; Sivakumar, K.; Bal, R. ChemistrySelect 2016, 1, 3075-3085. doi:10.1002/slct.201600685

41. Djaidja, A.; Libs, S.; Kiennemann, A.; Barama, A. Catal. Today 2006, 113, 194-200. doi:10.1016/j.cattod.2005.11.066 
42. Dong, W.-S.; Jun, K.-W.; Roh, H.-S.; Liu, Z.-W.; Park, S.-E. Catal. Lett. 2002, 78, 215-222. doi:10.1023/A:1014905318290

43. Pino, L.; Vita, A.; Cipitì, F.; Laganà, M.; Recupero, V. Appl. Catal., B: Environ. 2011, 104, 64-73. doi:10.1016/j.apcatb.2011.02.027

44. Zhang, S.; Muratsugu, S.; Ishiguro, N.; Tada, M. ACS Catal. 2013, 3 , 1855-1864. doi:10.1021/cs400159w

45. Frusteri, F.; Arena, F.; Calogero, G.; Torre, T.; Parmaliana, A. Catal. Commun. 2001, 2, 49-56. doi:10.1016/S1566-7367(01)00008-5

46. Snoeck, J.-W.; Froment, G.; Fowles, M. Ind. Eng. Chem. Res. 2002, 41, 4252-4265. doi:10.1021/ie010666h

47. Bachiller-Baeza, B.; Mateos-Pedrero, C.; Soria, M. A.; Guerrero-Ruiz, A.; Rodemerck, U.; Rodríguez-Ramos, I. Appl. Catal., B: Environ. 2013, 129, 450-459. doi:10.1016/j.apcatb.2012.09.052

48. Zarei, M.; Meshkani, F.; Rezaei, M. Adv. Powder Technol. 2016, 27, 1963-1970. doi:10.1016/j.apt.2016.06.028

49. Abdollahifar, M.; Haghighi, M.; Babaluo, A. A. J. Ind. Eng. Chem. 2014, 20, 1845-1851. doi:10.1016/j.jiec.2013.08.041

50. Daza, C. E.; Moreno, S.; Molina, R. Int. J. Hydrogen Energy 2011, 36, 3886-3894. doi:10.1016/j.jhydene.2010.12.082

51. Elsayed, N. H.; Roberts, N. R. M.; Joseph, B.; Kuhn, J. N. Appl. Catal., B: Environ. 2015, 179, 213-219. doi:10.1016/j.apcatb.2015.05.021

52. Fan, M.-S.; Abdullah, A. Z.; Bhatia, S. Appl. Catal., B: Environ. 2010, 100, 365-377. doi:10.1016/j.apcatb.2010.08.013

53. García-Vargas, J. M.; Valverde, J. L.; Díez, J.; Sánchez, P.; Dorado, F. Appl. Catal., B: Environ. 2015, 164, 316-323. doi:10.1016/j.apcatb.2014.09.044

54. Son, I. H.; Kwon, S.; Park, J. H.; Lee, S. J. Nano Energy 2016, 19 , 58-67. doi:10.1016/j.nanoen.2015.11.007

55. Xu, B.-Q.; Wei, J.-M.; Wang, H.-Y.; Sun, K.-Q.; Zhu, Q.-M. Catal. Today 2001, 68, 217-225. doi:10.1016/S0920-5861(01)00303-0

56. Nikoo, M. K.; Amin, N. Fuel Process. Technol. 2011, 92, 678-691. doi:10.1016/j.fuproc.2010.11.027

57. Wang, S.; Lu, G.; Millar, G. J. Energy Fuels 1996, 10, 896-904. doi:10.1021/ef950227t

58. Li, Y.; Wang, Y.; Zhang, X.; Mi, Z. Int. J. Hydrogen Energy 2008, 33, 2507-2514. doi:10.1016/j.ijhydene.2008.02.051

59. Shamsi, A.; Johnson, C. D. Catal. Today 2003, 84, 17-25. doi:10.1016/S0920-5861(03)00296-7

60. Sun, Y.; Ritchie, T.; Hla, S. S.; McEvoy, S.; Stein, W.; Edwards, J. H. J. Nat. Gas Chem. 2011, 20, 568-576. doi:10.1016/S1003-9953(10)60235-6

61. Zhang, Y.; Zhang, G.; Zhang, B.; Guo, F.; Sun, Y. Chem. Eng. J. 2011, 173, 592-597. doi:10.1016/j.cej.2011.08.008

62. Jafarbegloo, M.; Tarlani, A.; Mesbah, A. W.; Sahebdelfar, S. Int. J. Hydrogen Energy 2015, 40, 2445-2451. doi:10.1016/j.ijhydene.2014.12.103

63. Jafarbegloo, M.; Tarlani, A.; Mesbah, A. W.; Sahebdelfar, S. J. Nat. Gas Sci. Eng. 2015, 27, 1165-1173. doi:10.1016/j.jngse.2015.09.065

64. Klein, J. E. Fusion Sci. Technol. 2002, 41, 998-1003. doi:10.13182/FST02-A22734

65. Fan, M.-S.; Abdullah, A. Z.; Bhatia, S. ChemCatChem 2009, 1, 192-208. doi:10.1002/cctc.200900025

66. Niu, J.; Du, X.; Ran, J.; Wang, R. Appl. Surf. Sci. 2016, 376, 79-90. doi:10.1016/j.apsusc.2016.01.212
67. Nakamura, J.; Aikawa, K.; Sato, K.; Uchijima, T. Catal. Lett. 1994, 25, 265-270. doi:10.1007/BF00816306

68. Alipour, Z.; Rezaei, M.; Meshkani, F. J. Ind. Eng. Chem. 2014, 20, 2858-2863. doi:10.1016/j.jiec.2013.11.018

69. Khavarian, M.; Chai, S.-P.; Mohamed, A. R. Chem. Eng. J. 2014, 257, 200-208. doi:10.1016/j.cej.2014.05.079

70. Alipour, Z.; Rezaei, M.; Meshkani, F. J. Energy Chem. 2014, 23 , 633-638. doi:10.1016/S2095-4956(14)60194-7

71. Angeli, S. D.; Pilitsis, F. G.; Lemonidou, A. A. Catal. Today 2015, 242, 119-128. doi:10.1016/j.cattod.2014.05.043

72. Schulz, L. A.; Kahle, L. C. S.; Delgado, K. H.; Schunk, S. A.; Jentys, A.; Deutschmann, O.; Lercher, J. A. Appl. Catal., A 2015, 504, 599-607. doi:10.1016/j.apcata.2015.03.002

73. Wang, Z.; Cao, X. M.; Zhu, J.; Hu, P. J. Catal. 2014, 311, 469-480. doi:10.1016/j.jcat.2013.12.015

74. Saqib, N.; Porter, J. M. Sens. Actuators, B 2016, 224, 755-763. doi:10.1016/j.snb.2015.10.112

75. Singha, R. K.; Yadav, A.; Agrawal, A.; Shukla, A.; Adak, S.; Sasaki, T.; Bal, R. Appl. Catal., B: Environ. 2016, 191, 165-178. doi:10.1016/j.apcatb.2016.03.029

76. Luisetto, I.; Tuti, S.; Battocchio, C.; Lo Mastro, S.; Sodo, A. Appl. Catal., A 2015, 500, 12-22. doi:10.1016/j.apcata.2015.05.004

77. Lobo, L. S.; Figueiredo, J. L.; Bernardo, C. A. Catal. Today 2011, 178, 110-116. doi:10.1016/j.cattod.2011.07.030

78. Djaidja, A.; Messaoudi, H.; Kaddeche, D.; Barama, A. Int. J. Hydrogen Energy 2015, 40, 4989-4995. doi:10.1016/j.ijhydene.2014.12.106

79. Istadi, I.; Anggoro, D. D.; Amin, N. A. S.; Ling, D. H. W. Bull. Chem. React. Eng. Catal. 2011, 6, 129-136. doi:10.9767/bcrec.6.2.1213.129-136

80. Wei, J.; Iglesia, E. J. Catal. 2004, 224, 370-383. doi:10.1016/j.jcat.2004.02.032

81. Aparicio, L. M. J. Catal. 1997, 165, 262-274. doi:10.1006/jcat.1997.1468

82. Dehimi, L.; Benguerba, Y.; Virginie, M.; Hijazi, H. Int. J. Hydrogen Energy 2017, 42, 18930-18940. doi:10.1016/j.ijhydene.2017.05.231

83. Wang, S. Ind. Eng. Chem. Res. 1999, 38, 2615-2625. doi:10.1021/ie980489t

84. Bradford, M. C. J.; Vannice, M. A. Catal. Rev. 1999, 41, 1-42. doi:10.1081/CR-100101948

85. Lemonidou, A. A.; Vasalos, I. A. Appl. Catal., A 2002, 228, 227-235. doi:10.1016/S0926-860X(01)00974-7

86. Zhang, J.; Wang, H.; Dalai, A. K. Ind. Eng. Chem. Res. 2009, 48, 677-684. doi:10.1021/ie801078p

87. Joyner, R. W.; Pendry, J. B.; Saldin, D. K.; Tennison, S. R. Surf. Sci. 1984, 138, 84-94. doi:10.1016/0039-6028(84)90497-7

88. Julkapli, N. M.; Bagheri, S. Rev. Inorg. Chem. 2016, 36, 1-41. doi:10.1515/revic-2015-0010

89. Park, J. C.; Song, H. Nano Res. 2011, 4, 33-49. doi:10.1007/s12274-010-0039-z

90. Richardson, J. T. Principles of Catalyst Development; Springer : US, 1989.

91. Wang, H. Y.; Ruckenstein, E. Appl. Catal., A 2001, 209, 207-215. doi:10.1016/S0926-860X(00)00753-5

92. Perez-Lopez, O. W.; Senger, A.; Marcilio, N. R.; Lansarin, M. A. Appl. Catal., A 2006, 303, 234-244. doi:10.1016/j.apcata.2006.02.024

93. Serrano-Lotina, A.; Rodríguez, L.; Muñoz, G.; Daza, L. J. Power Sources 2011, 196, 4404-4410. doi:10.1016/j.jpowsour.2010.10.107 
94. Feng, J.; Ding, Y.; Guo, Y.; Li, X.; Li, W. Fuel 2013, 109, 110-115. doi:10.1016/j.fuel.2012.08.028

95. Bartholomew, C. H.; Farrauto, R. J. Fundamentals of Industrial Catalytic Processes, 2nd ed.; John Wiley \& Sons, Inc.: Hoboken, New Jersey, 2011.

96. Arora, S.; Prasad, R. RSC Adv. 2016, 6, 108668-108688. doi:10.1039/C6RA20450C

97. Ni, J.; Chen, L.; Lin, J.; Schreyer, M. K.; Wang, Z.; Kawi, S. Int. J. Hydrogen Energy 2013, 38, 13631-13642. doi:10.1016/j.ijhydene.2013.08.041

98. Liu, C.; Li, M.; Wang, J.; Zhou, X.; Guo, Q.; Yan, J.; Li, Y. Chin. J. Catal. 2016, 37, 340-348. doi:10.1016/S1872-2067(15)61020-8

99. Zou, J.-J.; Liu, C.-J.; Zhang, Y.-P. Langmuir 2006, 22, 2334-2339. doi:10.1021/la052135u

100.Liu, G.; Li, Y.; Chu, W.; Shi, X.; Dai, X.; Yin, Y. Catal. Commun. 2008, 9, 1087-1091. doi:10.1016/j.catcom.2007.10.013

101.Yan, X.; Liu, Y.; Zhao, B.; Wang, Z.; Wang, Y.; Liu, C.-j. Int. J. Hydrogen Energy 2013, 38, 2283-2291. doi:10.1016/j.ijhydene.2012.12.024

102. Yan, X.; Zhao, B.; Liu, Y.; Li, Y. Catal. Today 2015, 256, 29-40. doi:10.1016/j.cattod.2015.04.045

103. García, V.; Fernández, J. J.; Ruíz, W.; Mondragón, F.; Moreno, A. Catal. Commun. 2009, 11, 240-246. doi:10.1016/j.catcom.2009.10.003

104.Min, J.-E.; Lee, Y.-J.; Park, H.-G.; Zhang, C.; Jun, K.-W. J. Ind. Eng. Chem. 2015, 26, 375-383. doi:10.1016/j.jiec.2014.12.012

105.Zhu, J.; Peng, X.; Yao, L.; Shen, J.; Tong, D.; Hu, C. Int. J. Hydrogen Energy 2011, 36, 7094-7104. doi:10.1016/j.ijhydene.2011.02.133

106.Xu, Y.; Long, H.; Wei, Q.; Zhang, X.; Shang, S.; Dai, X.; Yin, Y. Catal. Today 2013, 211, 114-119. doi:10.1016/j.cattod.2013.03.007

107.Serrano-Lotina, A.; Rodríguez, L.; Muñoz, G.; Martin, A. J.; Folgado, M. A.; Daza, L. Catal. Commun. 2011, 12, 961-967. doi:10.1016/j.catcom.2011.02.014

108.Meshkani, F.; Rezaei, M.; Andache, M. J. Ind. Eng. Chem. 2014, 20, 1251-1260. doi:10.1016/j.jiec.2013.06.052

109.Lin, L.; Zhang, L.-m.; Zhang, Y.-h.; Li, J.-I. J. Fuel Chem. Technol. (Beijing, China) 2015, 43, 315-322. doi:10.1016/S1872-5813(15)30007-4

110. Khajenoori, M.; Rezaei, M.; Meshkani, F. J. Ind. Eng. Chem. 2015, 21, 717-722. doi:10.1016/j.jiec.2014.03.043

111. Meshkani, F.; Rezaei, M. J. Nat. Gas Chem. 2011, 20, 198-203. doi:10.1016/S1003-9953(10)60169-7

112.Zhu, Y.; Zhang, S.; Chen, B.; Zhang, Z.; Shi, C. Catal. Today 2016, 264, 163-170. doi:10.1016/j.cattod.2015.07.037

113. Yu, X.; Wang, N.; Chu, W.; Liu, M. Chem. Eng. J. 2012, 209, 623-632. doi:10.1016/j.cej.2012.08.037

114.Sengupta, S.; Deo, G. J. CO2 Util. 2015, 10, 67-77. doi:10.1016/j.jcou.2015.04.003

115. Charisiou, N. D.; Baklavaridis, A.; Papadakis, V. G.; Goula, M. A. Waste Biomass Valorization 2016, 7, 725-736. doi:10.1007/s12649-016-9627-9

116.Akbari, E.; Alavi, S. M.; Rezaei, M. Fuel 2017, 194, 171-179. doi:10.1016/j.fuel.2017.01.018

117.Jabbour, K.; Massiani, P.; Davidson, A.; Casale, S.; El Hassan, N. Appl. Catal., B: Environ. 2017, 201, 527-542. doi:10.1016/j.apcatb.2016.08.009

118.Li, Z.; Kathiraser, Y.; Ashok, J.; Oemar, U.; Kawi, S. Langmuir 2014 30, 14694-14705. doi:10.1021/la503340s
119.Wang, N.; Yu, X.; Shen, K.; Chu, W.; Qian, W. Int. J. Hydrogen Energy 2013, 38, 9718-9731. doi:10.1016/j.ijhydene.2013.05.097

120.Macedo Neto, O. R.; Ribeiro, N. F. P.; Perez, C. A. C.; Schmal, M.; Souza, M. M. V. M. Appl. Clay Sci. 2010, 48, 542-546. doi:10.1016/j.clay.2010.02.015

121.Yan, Z.-F.; Ding, R.-G.; Liu, X.-M.; Song, L.-H. Chin. J. Chem. 2001, 19, 738-744. doi:10.1002/cjoc.20010190806

122. Alipour, Z.; Rezaei, M.; Meshkani, F. Fuel 2014, 129, 197-203. doi:10.1016/j.fuel.2014.03.045

123. Mirzaei, F.; Rezaei, M.; Meshkani, F.; Fattah, Z. J. Ind. Eng. Chem. 2015, 21, 662-667. doi:10.1016/j.jiec.2014.03.034

\section{License and Terms}

This is an Open Access article under the terms of the Creative Commons Attribution License

(http://creativecommons.org/licenses/by/4.0), which permits unrestricted use, distribution, and reproduction in any medium, provided the original work is properly cited.

The license is subject to the Beilstein Journal of

Nanotechnology terms and conditions:

(https://www.beilstein-journals.org/bjnano)

The definitive version of this article is the electronic one which can be found at: doi:10.3762/bjnano.9.108 